\title{
The "medullosalean forest" at the Lloyd Cove Seam (Pennsylvanian, Sydney Coalfield, Nova Scotia, Canada)
}

\author{
ERWIN L. ZODROW
}

Department of Geology, University College of Cape Breton, Sydney, Nova Scotia, Canada B1P 6L2 <Erwin_Zodrow@uccb.ns.ca> Date received:December 3, 2002 I Date accepted:April 16, 2003

\begin{abstract}
From a ca. 4,200 m+2 mining area of the roof shale of the Lloyd Cove Seam, Sydney Coalfield, Nova Scotia, an alethopterid-linopterid assemblage was discovered. Physically associated with, and not connected with leaf fragments, is a great abundance of medullosalean axes and stems. They range in length from several to over $130 \mathrm{~cm}$, with attached axes of similarly variable lengths. Among them is a $130 \mathrm{~cm}$ long stem or trunk with "naked" $4-6 \mathrm{~cm}$ wide petioles in life position that are preserved for a maximum length of $60 \mathrm{~cm}$; it represents an arborescent alethopterid, or "seed-fern" tree, $5-7 \mathrm{~m}$ tall, with as yet undetermined frond structure and foliar species. These fossil finds are interpreted to represent a "medullosalean forest" whose habitat was within the drier parts of a coastal-plain ecosystem of basal Stephanian age, at which time floral changes occurred at the Lloyd Cove Seam. This discovery is unequalled in the Canadian Carboniferous Maritimes Basin, where macrofossil collections date back to the 1840s.
\end{abstract}

\section{RESUMÉ}

\begin{abstract}
On a découvert à l'intérieur d'un secteur d'extraction d'environ 4200 mètres carrés du schiste supérieur de l'anse Lloyd, dans le terrain houiller de Sydney, en Nouvelle-Écosse, un assemblage d'aléthoptérides et de linoptérides. On trouve une grande abondance de tiges et d'axes médullosaléens physiquement associés, mais non rattachés, à des fragments de feuilles. Ceux-ci varient d'une longueur de plusieurs centimètres à plus de $130 \mathrm{~cm}$, et comporte des axes de longueur similairement variables y étant rattachés. On trouve parmi eux une tige ou un tronc de $130 \mathrm{~cm}$ de longueur muni de pétioles « dénudés » de quatre à six centimètres de largeur, en position de vie, qui ont été conservés sur une longueur maximale de $60 \mathrm{~cm}$. Cette tige représente un aléthoptéride arborescent, ou un arbre d'origine « ptéridospermale » de cinq à sept mètres de hauteur dont la structure des frondes et l'espèce foliaire restent encore indéterminées. Ces découvertes de fossiles sont interprétées comme des représentants d'une « forêt médullosaléenne » dont l'habitat se trouvait à l'intérieur des secteurs les plus secs de l'écosystème d'une plaine côtière remontant au début du Stéphanien, moment où sont survenus des changements floraux dans le filon de l'anse Lloyd. Cette découverte ne correspond à aucun équivalent dans le bassin carbonifère des Maritimes canadien, où les prélèvements de macrofossiles remontent aux années 1840 .
\end{abstract}

\section{INTRODUCTION}

Literature on medullosalean pteridosperms, in contrast with other studied groups of Carboniferous plants, is very large and reflects a most intensively investigated Palaeozoic plant group. There are two lines of mutually supportive investigations relating to this group. One is based on coal-ball studies that reveal threedimensional anatomical, histological, and palaeoecological information (e.g., Basinger et al. 1974; Philips et al. 1985; Pryor 1990). By the nature of inherent limited size, coal balls cannot preserve the large parts of the fronds known to be borne by the arborescent alethopterid plant. The other is based on impression-compression structures, as is the present study, collected from an open-pit coal mine from which very large-sized plant structures can be recovered. The compression material furnishes the largest specimens for reconstructing these ancient gymnosperms (summaries: Pfefferkorn et al. 1984; Wnuk and Pfefferkorn 1984; Laveine et al. 1993; Laveine 1997; present study). These two investigative lines are skilfully integrated in discussions summarized by Laveine et al. (1993) who argued for a bifurcate alethopterid frond, that, however, remains to be demonstrated (but see Ramanujam et al.
(1974, fig. 24) who interpret alethopterid-frond structure to consist of proximal dichotomous branching).

The present study material originated from the Canadian Sydney Coalfield, Nova Scotia (Fig. 1a, b) at the Lloyd Cove Seam (Fig. 1c) that is basal Stephanian (Zodrow and Cleal 1985; Cleal et al. 2003; Cleal et al. 2002). The seam has been sampled by the author on strike for $5 \mathrm{~km}$ since it was open-pit mined, starting in 1980. During these activities, several distinct two-genera/species florules have been documented from the roof shale at various mining sites. Included are (1) a pecopterid-cordaites forest (Zodrow 1990; Zodrow et al. 2000) that fits Darrah's (1969, p. 68) concept of a two-species florule, with cordaites being the common floral element, (2) a site in which exclusively detached foliage of Neuropteris ovata was found together with striated axes, (3) a site overly abundant with Sphenophyllum oblongifolium and Leeites oblongifolis, and (4) a site with abundant Linopteris obliqua. Lycophytes, alethopterids, dicksoniteds, and calamites are rare to very rare occurrences at the above-mentioned four sites.

The Lloyd Cove Seam contrasts with other coal seams of the Sydney Coalfield, and with other coal seams of the same age, in having plentiful occurrences of naturally macerated cuticles of 


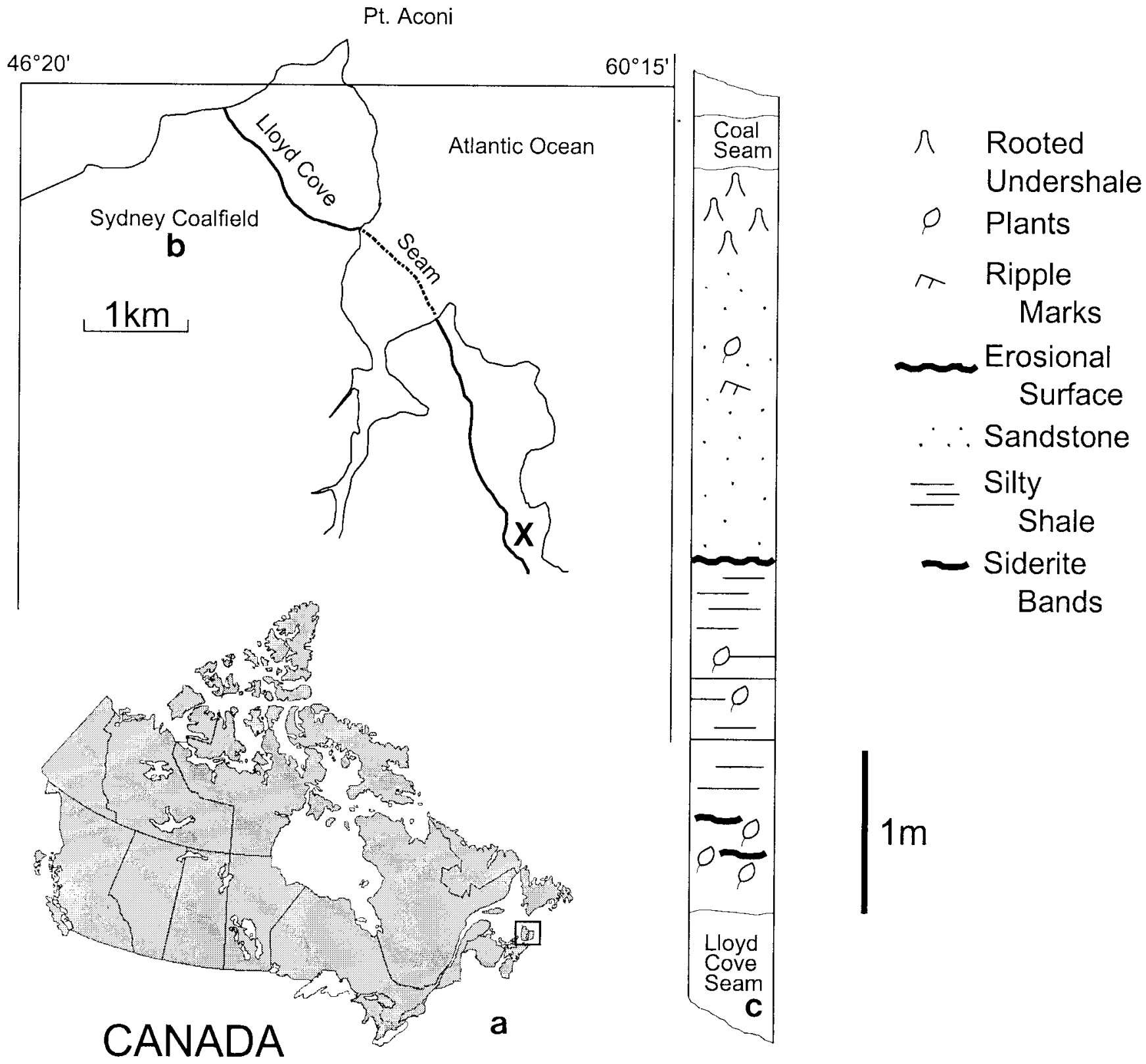

FIG. 1 (a) Canadian location map; (b) northern part of the Sydney Coalfield, where X indicates the present open-pit mining and sampling area. (c) local stratigraphic column of the Lloyd Cove Seam measured by the author.

odontopterids, sphenopterids, linopterids, sphenophylls, and pecopterids (Zodrow and Mastalerz 2001; 2002). Further, foliage at this seam invariably has intact cuticles because of higher- preserved levels of volatiles (Barthel 1962) which are due to low thermal activity and tectonism (Hacquebard and Cameron 1989).

The site at the Lloyd Cove Seam (Fig.1b, marked X) from which the present study specimens were collected is a first Canadian record of a florule dominated by foliage of Alethopteris and Linopteris. These finds are discussed and interpreted in this paper.

\section{DEPOSITORY}

The study material is represented by approximately 1,500 macrofossils that are preserved on 140 properly documented and curated silty-shale slabs with designated accession number, e. g., 002(GF)-221. These and the cuticular slides of the alethopterid foliage are part of the Palaeobotanical Collections of the University College of Cape Breton, Sydney, Nova Scotia, Canada, with the author being the curator. For brevity, authorships of individual taxa are not included in the main text, but rather within Appendix 1. 


\section{METHODS AND DEFINITIONS}

Maceration techniques for obtaining cuticles are detailed by Zodrow and Cleal (1998). However, maceration time for the investigated alethopterid cuticles is an unprecedented 12-60 hr. procedure in Schulze's solution we normally use. In general, alethopterid epidermal features are inconsistently preserved (noting that only freshly split compressions were used). Pinnules exposed to air in the open-pit mine yielded useless cuticles because of extreme fragmentation due to loss of volatiles (see Barthel 1962; Hacquebard and Cameron 1989). Strongly developed compression margins prevented separation of the surfaces at margins that otherwise came apart by themselves across the midvein while still in the alkaline solution.

Following Barthel's (1961, pl. II:3) investigative technique, selected alethopterid compressions were only macerated for a few hrs. (= macerated-only specimens) to be able to study midvein, lateral-vein, and subsidiary-vein morphologies, in relation to the ultimate-pinna rachis.

The basic investigative technique used in this study is degaging, a process by which parts of a macrofossil that are still covered by rock matrix were systematically exposed by very careful digging, first with blunt metal chisels of diminishing sizes, then finishing with very fine-pointed needles to the limit of the entombing rock collected. Precision degaging was done under a stereomicroscope to probe primary rachides for secondary-pinna attachment, ultimate rachides for foliar attachment, and to expose ramifications of asymmetrical branching (e.g., Fig. 9) for accurate width and angular-separation measurements (Table 1).

Nomenclature consistently used, as advocated by Laveine (1997) for description of a hypothetical bifurcate, pinnate frond of the type Neuralethopteris is followed.

\section{DESCRIPTION OF MATERIAL AND FLORAL ASSOCIATION}

The two main lithological units between the roof of the Lloyd Cove and the floor of the thin coal seam above it (Fig. 1c) are comprised of (1) silty-shale and (2) cross-laminated sandstone units, respectively, which are separated by an erosional surface. As such, this sequence is part of a cyclothem (Gibling and Bird 1994) in a terrestrial environment of an extensive costal platform (Wightman et al. 1994). The presence of siderite bands in the roof rocks (see below) confirms a non-marine influence here.

\section{(1) Silty-shale unit}

The silty-shale roof is $\pm 200 \mathrm{~cm}$ thick. It contains abundant sideritic bands $(c a .40 \% \mathrm{Fe})$, maximally $8-10 \mathrm{~mm}$ thick, and siderite nodules both of which are characteristic of the Lloyd Cove Seam. These occur most abundantly within $40-60 \mathrm{~cm}$ of the roof, and thereafter are absent, as Eh-pH conditions and supply of iron and carbonate changed. Some of the siderite nodules have preserved floral elements (Pecopteris unita, calamites stems), as are known from the famous Mazon-Creek Flora of Illinois, U.S.A. (see Darrah
Table 1. Asymmetric medullosalean axes.

\begin{tabular}{lccc}
\hline & $\begin{array}{c}\text { width of ramifications } \\
(\mathrm{mm})^{\mathrm{a}}\end{array}$ & $\begin{array}{c}\text { external angle } \\
\text { (in degrees) }\end{array}$ \\
Accession no. & wider & narrower & \\
\hline 002GF-247 (Fig. 9) & 14.5 & 12.5 & 160 and 140 \\
002GF-242 (Fig. 8) & 14.0 & 5.0 & 125 and 150 \\
002GF-250 & 10.0 & 8.0 & 150 and 110 \\
002GF-248 & 9.0 & 3.5 & 150 and 120 \\
\hline
\end{tabular}

${ }^{\mathrm{a}}$ Measured orthogonally across the ramification at $0.5 \mathrm{~cm}$ distance above the "Y" fork.

${ }^{\mathrm{b}}$ Measured between the ramification and the "Y" prolongation, left and right, respectively. In a normal branching situation, one of these angles should be close to 180 degrees, i.e., geometrically implying a straight axis.

1969). The siderite occurrences are used as a specific marker horizon to estimate proximity to the roof of the Lloyd Cove Seam of fragmentary slabs collected from the stone heap (waste rocks or spoils).

The flora was extensively sampled from the accumulated stone heap that represents a $c a .4,200 \mathrm{~m}+2$ area of the roof rocks mined in July and October of 2002. The floral components comprise a near-exclusive alethopterid-linopterid assemblage (Table 2). This compares with a total seed-plant average of 25 species for Pennsylvanian floras based on compression-roof, and coal-ball floras from the USA and NW German Coal Measures (DiMichele et al. 2001: table 11.3). Moreover, medullosalean axes of varying thicknesses are also extremely abundant. The macrofloral fossil content decreases drastically, and is near zero, in the upper part, $170 \mathrm{~cm}$ or so, of the silty-shale unit (Fig. 1c).

\section{Vascular part of a medullosalean stem}

Figure 2 represents a first record from the Canadian Carboniferous of a medullosalean-impression fragment, in part preserved in siderite (and therefore from within a short distance from the roof). It is approximately $15 \mathrm{~cm}$ long and $8 \mathrm{~cm}$ wide, and some sort of a cuticular structure is preserved, judging from the brownish-looking surface that is finely granulate (Basinger et al. 1974). The significance of this find remains to be seen and cannot be properly interpreted until more material can be collected.

\section{Fragmentary medullosalean stems and axes}

Physically associated with the flora is a plethora of fragmentary axes of various dimensions from 0.5 to over $13 \mathrm{~cm}$ in width, and up to $130 \mathrm{~cm}$ in length, after fragmentation by open-pit mining methods. They all show longitudinally striated or ridge-valley structures that extend into the petioles to form medial ridges (see also Gastaldo 1990). These represent cortical sclerenchymatous fibres or bundles that are characteristic of younger medullosalean stems and axes, and played a supporting role (Stewart 


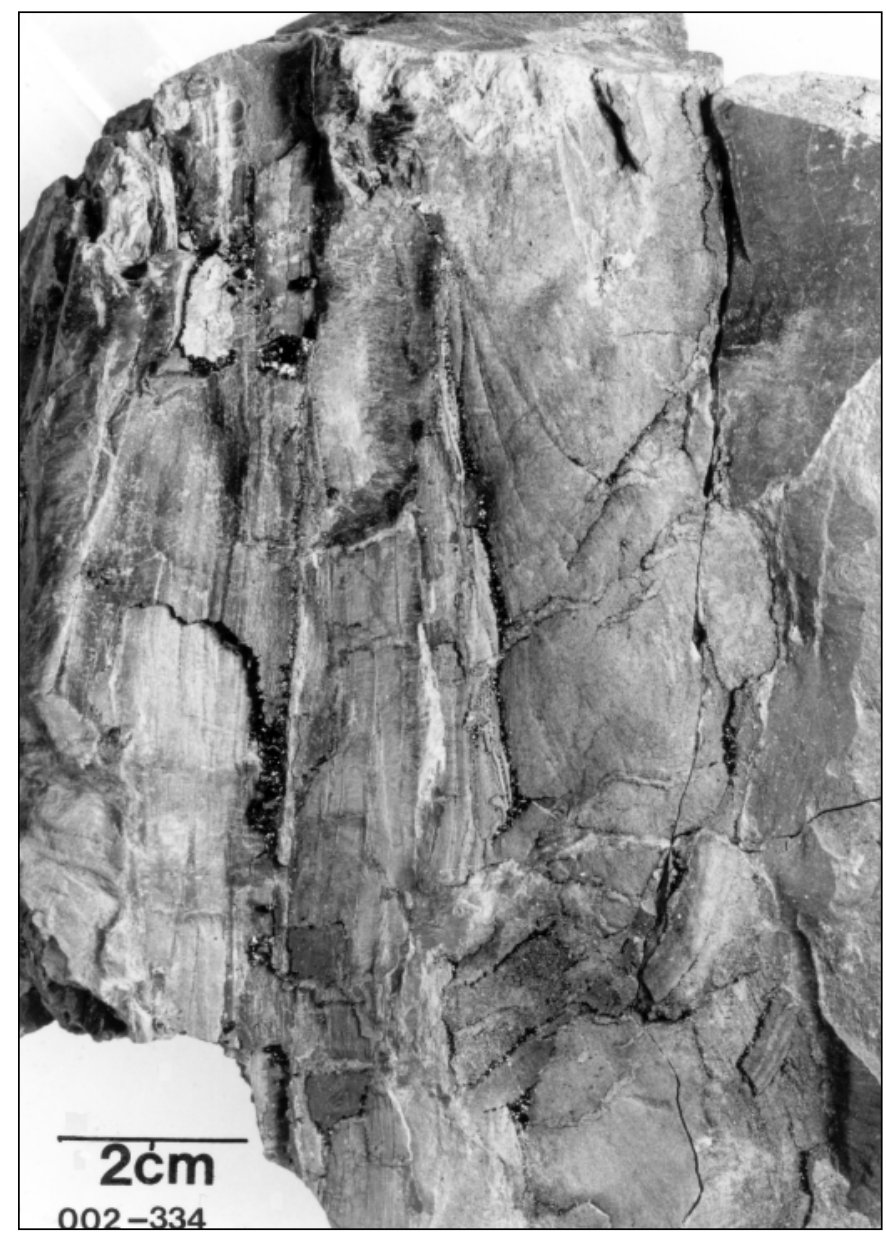

FIG. 2 Impression of a medullosalean stem. 002GF-334.

and Delevoryas 1956; Basinger et al. 1974; Remy and Remy 1977; Pfefferkorn et al. 1984; Laveine 1986; Gastaldo 1990). None of the axes has organically attached foliage, and all show submillimetresize rosettes of iron-copper sulphide (pyrite, chalcopyrite: indicative of locally strong reducing conditions, Eh $c a$. -0.3 , Garrels and Christ 1965). These minerals are absent on the structure depicted in Fig. 3.

Of particular interest, because of its large recovered size, is a petiolate stem that shows 12 fibres/linear $\mathrm{cm}$ near the top and 14 - 15 near the bottom, and which has rare remnants of a coalifiedstem compression $10-13 \mathrm{~cm}$ long (Fig. 3). The stem is ca. $130 \mathrm{~cm}$ long, appears uniformly $13 \mathrm{~cm}$ wide (but thickening below petioles is observed), and shows 7 petioles, numbered " 1 to 7 " in Fig. 4. They range in width from $4-6 \mathrm{~cm}$, are entirely "naked", i.e., without laminate (leafy) structure, and do not show a dichotomy for their preserved length of up to $60 \mathrm{~cm}$. This, and an additional much shorter stem (Fig. 5), is impression-preserved on a secured $155 \mathrm{~cm}$ by $110 \mathrm{~cm}$ by $30 \mathrm{~cm}$ silty-shale slab (weighing $c a .315 \mathrm{~kg}$ ). Spacing between petioles is seemingly uneven, from $12-45 \mathrm{~cm}$. The latter figure is probably biased, as between petiolar locations "4" and "7" (Fig. 4) the erosional surface is below the stratigraphic level on which the stem is imprinted. Petioles " $1,3,4$ and 7" clearly are in life position, whereas " 5 " could be associated with "6" (Figs. 4, 6), or it represents attachment to the hidden side of the stem. The presence of petioles " 2 " and " 6 " is each represented by a scar, as inferred from convergence of the cortical fibres. Proximally on " 4 " is a disruption of such structure but this does not necessarily have to be interpreted as a scar. The down-bent petioles in the upper part of the stem probably signify position after death. Closer examination of the edges of this silty-shale slab shows the presence of many additional striated, $4-5 \mathrm{~cm}$ wide axes with medial ridges, and indications of abundant foliage.

Two architecturally different rachides are recognizable among the many found, collected, and degaged axes. One is exemplified (Fig. 7) by a tripinnate, $65 \mathrm{~cm}$ long, striate, fragmentary primary rachis, $2 \mathrm{~cm}$ wide near the base, and $1.4 \mathrm{~cm}$ near the top; secondary rachides are oppositely placed, also striate, $1-0.7 \mathrm{~cm}$ wide, and preserved for a length of $13 \mathrm{~cm}$. These show suboppositelyplaced bases of ultimate-pinna rachides, $c a .2 \mathrm{~mm}$ wide, that are separated by $3-6 \mathrm{~cm}$, depending on position on the primary pinna.

The other configuration is represented by shorter, fragmentary, "Y"-shaped axes. These show that one of the two ramifications is consistently narrower than the other (Figs. 8,9). Although the difference is measured in terms of millimetres only (Table 1), it is deemed significant to signify morphological asymmetry, as experimental methods have demonstrated that compression results more in a biased length than width (Rex and Chaloner 1983). Asymmetry is furthermore confirmed by the unequal exterior angles between the "Y" prolongation. The lack of mirror-image symmetry (see Frye 1993, p. 106) precludes interpreting the "Y's" as dichotomously-branching axes. In specimens with narrower ramifications, asymmetry is comparatively less pronounced, forming a more normal-branching axis (compare Buisine 1961 pl. 33, fig. 2). Also, consistently observed on both ramifications, and on prolongations of asymmetric fragments, are $2-3 \mathrm{~mm}$ wide rachial bases that are generally preserved for less than $1 \mathrm{~cm}$ in length. On these there are also preserved, sporadically, oppositely placed axial bases that are $1 \mathrm{~mm}$ wide.

\section{Alethopterid compression and midvein-epidermal morphologies}

Figure 10 conveys a sense of the abundance of densely-occurring detached, fragmentary ultimate-alethopterid pinnae, and caducous linopterid pinnules that are associated with the medullosalean axes throughout the sample area.

Figure 11a shows the tip region of a primary or secondary pinna with $2 \mathrm{~cm}$ long pinnules homologous to ultimate pinnae, which then change to pinnatifid pinnules in which subsidiary veins tend to dominate. A short midvein is present with maximally two uneven forkings. The lateral-vein pattern is self-similar (see Heggie and Zodrow 1994) to that which occurs in near-tip pinnules of an ultimate pinna (see Fig. 11b). Ultimate pinnae are generally linear in outline and show undifferentiated terminal pinnules (Fig. 11b), and in life these pinnae must have been quite long, judging from the fragmentary specimen that is preserved for $15 \mathrm{~cm}$. Towards the base of an ultimate pinna, pinnules developed neuropteroid attachment (having lost both basiscopic sinus, and acroscopic constriction; Fig. 11c). 
Table 2. Subjective percentage estimates of floral composition in the \pm 200 -cm silty-shale unit (roof) of the Lloyd Cove Seam, Sydney Coalfield, Cape Breton Island, Nova Scotia.

$\begin{array}{ll}\text { Undetermined alethopterid foliage } & 60 \text { to } 90 \% \text {, this includes a miniscule percentage point of } A \text {. ambigua } \\ \text { Linopterid foliage } & 10 \text { to } 40 \%, \text { as L. obliqua and L. brongniartii } \\ \text { Medullosalean axes } & 5-15 \%\end{array}$

Less than $1 \%$, in decreasing order of abundance

Medullosalean ovules

Roots?

Laveineopteris rarinervis

Sphenophyll species (S. emarginatum, S. oblongifolium, S. costae, S. cuneifolium forma ampulum)

Pecopterids (P. abbreviata, P. unita, P. hemitilioides? [fertile], Acitheca polymorpha)

Sphenopterids s. 1 .

Alethopteris ambigua

Lycophytes, roots?, cone and leaves, trunk impression (3 specimens)

Dicksonites plueckenetii

Annularia sp.

Cordaites sp. (one fragment)

Neuropteris ovata (one specimen)

Neuropteris cf. flexuosa (one specimen)

Macroneuropteris macrophylla (one specimen)

Aphlebia sp. (one 15-cm specimen)

Absent are:

Sigillarians, odontopterids, mariopterids, calamites, eusphenopterids, cyatheoids

This is based on 3-week fieldwork collecting by the author, August-September, and November 2002.

Pinnules reach a maximum length of just over $2 \mathrm{~cm}$ and $0.7-0.8 \mathrm{~cm}$ width, being slightly convex acroscopically, with a round apex, and near parallel margins, except in the distal part where they are not. Macerated-only specimens and cuticles show strongly developed compression margins that are $800-900 \mu \mathrm{m}$ wide bordering a pinnule. Moreover, the midvein is demonstrably non-decurrent (Fig. 12a), and basal veins arise directly from the ultimate-pinna rachis (Fig. 12b). Adaxial and abaxial midveins of one pinnule also show different widths, epidermal morphologies, and differing degrees of cutinization. On adaxial surfaces (Fig. 13a), the midvein does not vary much in width, from $17 \mu$ m near the base, tapering slightly to $15 \mu \mathrm{m}$ near the apex of a pinnule. Its epidermal cells arise directly from an ultimate pinna rachis (see also Fig. 12a), are aligned, mostly rectangular-elongate, rarely spindle-form in outline, and are $30-156 \mu \mathrm{m}$ long and $11-27 \mu \mathrm{m}$ wide. Anticlinal cell walls are $8-11 \mu \mathrm{m}$ thick; some lateral walls are concave, and highly cutinized. On abaxial cuticles (Fig. 13b), the midvein varies in width from $700-1,000 \mu \mathrm{m}$ near the base, from $400-600 \mu \mathrm{m}$ in the upper part, and is $40 \mu \mathrm{m}$ wide where it breaks up into simple lateral veins $c a .1,500 \mu \mathrm{m}$ below the apex. Its epidermal cells also arise directly from the ultimate pinna rachis, are aligned and comparatively very irregularly shaped, as spindleforms, sphenoidal, sausage-like, rectangular with angular and rounded corners, and near-square; length varies from $34-133$ $\mu \mathrm{m}$, and width from $12-30 \mu \mathrm{m}$. Trichomal bases are abundant,
$27-42 \mu \mathrm{m}$ in diameter (larger ones are oval in shape), and show "ringed cellular structure". Trichomes are not preserved.

On the basiscopic side of the larger pinnules, lateral veins emerge obliquely from the midvein, fork, and fork again closer to the margin than to the midvein to reach the margin at an oblique angle (Fig. 14). The venation pattern represents maximum twovein forkings, which reduces to 1-1/2, once forking, to simple veins near tip and base as rachial veins. On the acroscopic side of the same pinnule, the lateral veins are much more horizontally inclined due to compressed space, or taphonomic influence. Vein density per marginal $\mathrm{cm}$ is 28 , i.e., a rather loose pattern.

Adaxial cuticles are thick and very cutinized, and epidermal structure is strongly differentiated between intercostal and costal fields. Intercostal cells are very irregular in shape, from near isodiametric, quasi-square, elongate polygonal, doubly to tribulbous with curved to semisinusoidal walls (Figs. 12b, 13a, 15a). The long axes are irregularly aligned with each other (Fig. 15b). Length varies from $49-103 \mu \mathrm{m}$, and width from $27-57 \mu \mathrm{m}$. Anticlinal walls are $3-8 \mu \mathrm{m}$ wide. Costal fields show mostly aligned, elongate, subrectangular cells with round corners and straight or curviflexuous anticlinal walls. Length varies from $50-144 \mu \mathrm{m}$ and width from $15-35 \mu \mathrm{m}$ (Fig. 15a).

Abaxial cuticles are comparatively very thin and delicate, and much less cutinized. Epidermal structure is not known to be differentiated, as intercostal cells were not observed, but rare 


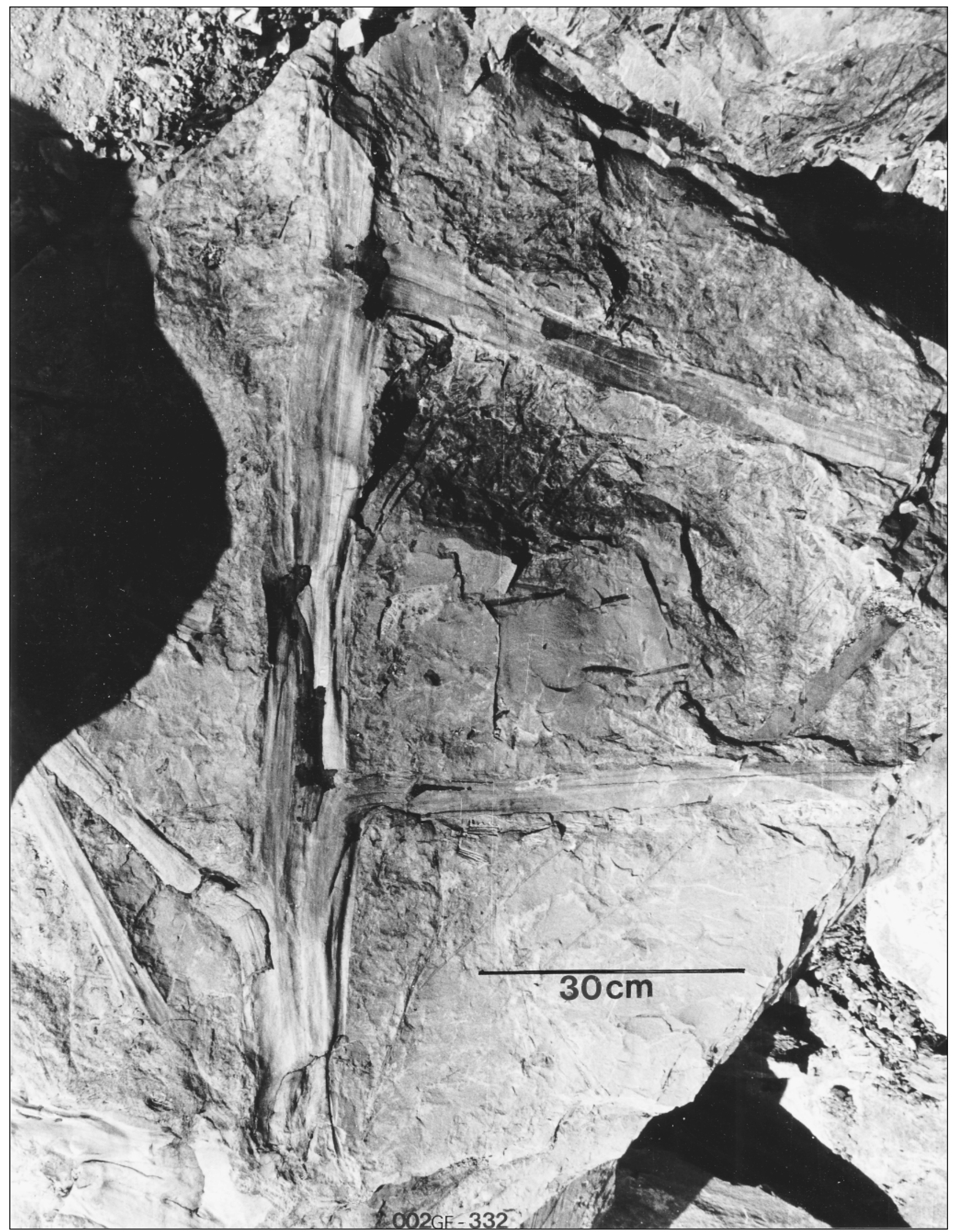

FIG. 3 Photograph of the $1.3 \mathrm{~m}$ long and $13 \mathrm{~cm}$ wide fragmentary, medullosalean-petiolate stem (shadow at left is unavoidable because of mining equipment); see line drawing in Fig. 4. Note "naked" petioles (no lamina). 002GF-332. 


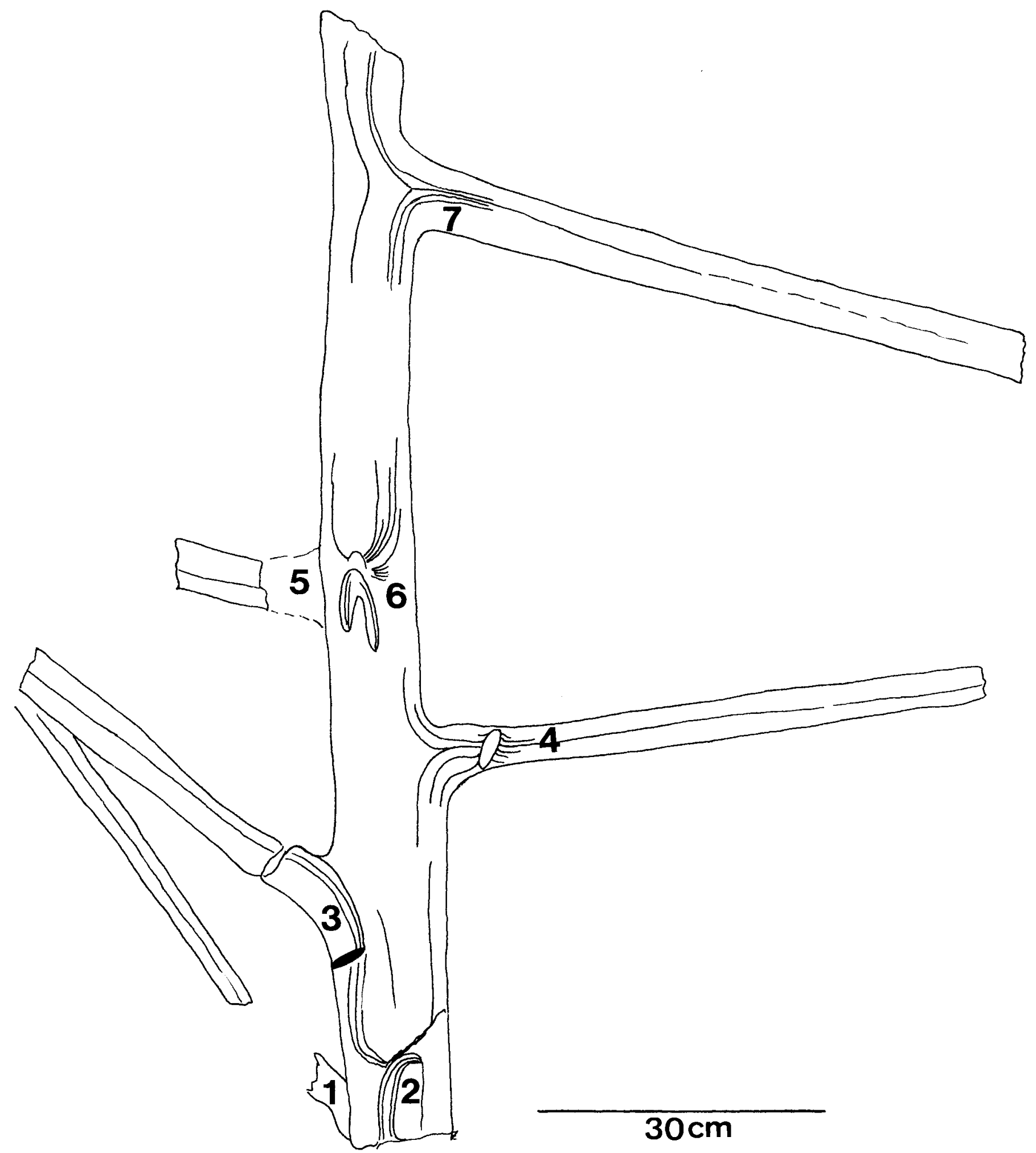

FIG. 4 Line drawing of the medullosalean-petiolate stem in Fig. 3, identifying "1 to 7" petiolar structures, and schematic outline of sclerenchymatous fibres. 
trichomal bases are present in intercostal fields (ca. $26 \mu \mathrm{m}$ ). Costal cells are similar in size and shape to adaxial costal cells. Structure of stomata could not be determined.

\section{Linopterid compression foliage}

The second most abundant co-floral component (Table 2) comprises the combined linopterid forms $L$. brongniartii and $L$. obliqua. Wnuk and Pfefferkorn (1984, fig. 14) proposed a quadripinnate frond structure for the latter. L. obliqua was diagnosed and erected as a new species by Bell (1938), and both species are morphometrically and morphologically compared by Zodrow and McCandlish (1978). During the present study, these two forms occur notably as abscised pinnules, very rarely as ultimate pinnae of which three were collected. Cuticles were not prepared, but previous preparations showed thin surfaces that fragmented along aeriolae which makes separation of abaxial from adaxial surfaces next to impossible.

\section{Detached medullosalean ovules}

Detached medullosalean ovules are common. Based on their magnitude and external topography of what is preserved, they are categorized as follows: (a) Rhabdocarpus form; $8-9 \mathrm{~cm}$ long, $4 \mathrm{~cm}$ wide, and pointedly oval-shaped; one prominent medial rib is shown which has $8-10$ parallel thin lines on either side, separated from each other by $2 \mathrm{~mm}$ (Fig. 16a, b). Observed in several collections are ovules that occur in single file, as if arranged along either side of an axis (Fig. 16a). Most of the ovules show "slickensided" margins that probably resulted from these large (heavy?) ovules dropping into the mud flats. (b) TrigonocarpusHolcospermum form (Zodrow 1986, pl. III); ca. $3 \mathrm{~cm}$ long, $2 \mathrm{~cm}$ wide, ovally shaped; one prominent rib with 3 - 4 less prominent ribs on either side (Fig. 16c); and (c) $1.5-2 \mathrm{~cm}$ long, subtriangularly shaped and pointed, $1-1.5 \mathrm{~cm}$ wide, ovules (of linopterid affinity?) (Fig. 16d).

\section{Roots and root mantle}

Occasionally, isolated $4-11 \mathrm{~mm}$ wide, up to $25 \mathrm{~cm}$ long fragmentary linear structures occur, without carinae. These could be construed as medullosalean roots. However, one specimen, $22 \mathrm{~cm}$ wide, with intact attached adventitious roots (Fig. 17), is the only known root mantle from the Canadian Carboniferous Maritimes Basin. The base of each root at the stem is bulbous, about $2.5 \mathrm{~cm}$ wide; the roots are maximally $12 \mathrm{~mm}$ wide, and they are arranged in dense, overlapping configuration.

\section{(2) Cross-laminated sandstone unit}

The succeeding cross-laminated, micaceous-sandstone unit is ca. $200 \mathrm{~cm}$ thick and, in stark contrast with the silty-shale unit, is only sparingly macrofossiliferous. Preserved for the most part is neuropterid foliage (see also Zodrow and Cleal 1988) and Laveineopteris rarinervis. Macroneuropterids are absent, but upright calamite stems (not found rooted) of the type $C$.

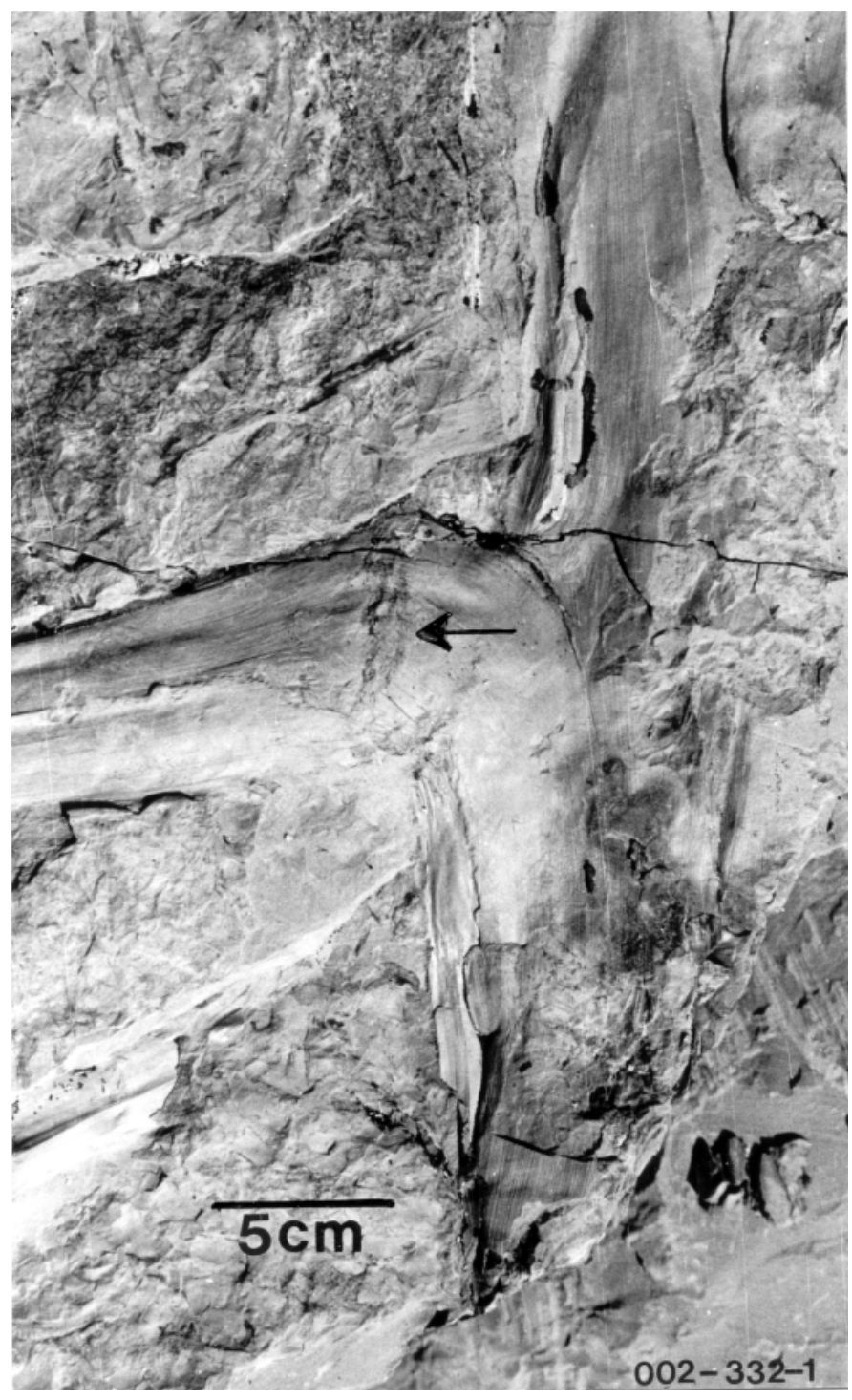

FIG. 5 A second short, fragmentary-petiolate stem that shows thickening below the petiole which appears broken (arrowed), similar to "3" (Fig. 3). 002-332-1

multiramis, and dicksonitids are present, the latter as naturally macerated cuticle.

\section{DISCUSSION}

\section{General}

The collection of the medullosalean-petiolate stem impression represents a rare Carboniferous find (Pfefferkorn et al. 1984; Wnuk and Pfefferkorn 1984), and a first record for Canada. However, it attains scientific significance in the context of all of the other fossil plants found with it.

It is enigmatic that, although the medullosalean foliage is well preserved in morphological detail, none of the axes observed in the field, including those that were degaged, show any evidence of 


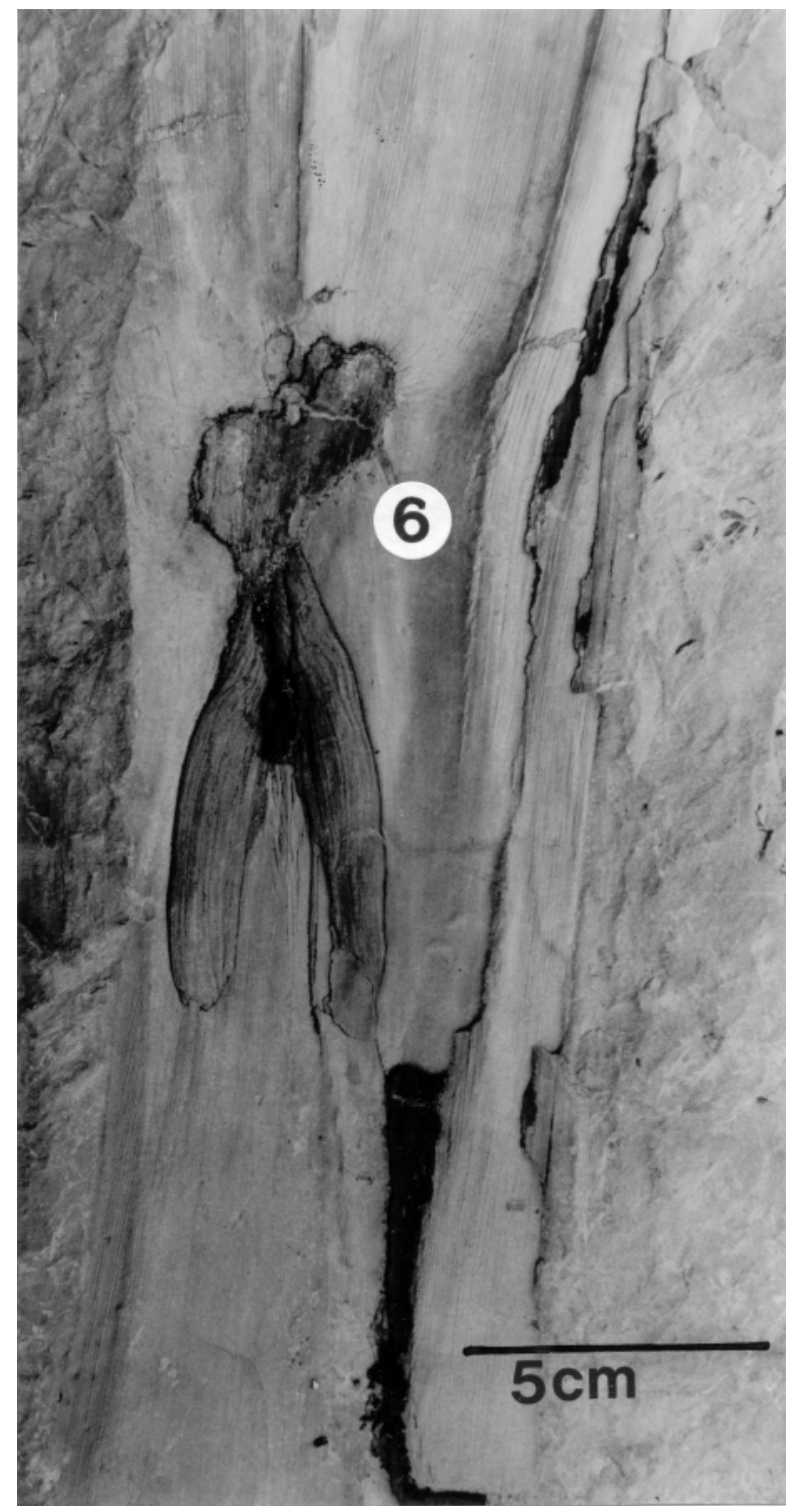

FIG. 6 Detail of the "horse-shoe-like" scar "6"(Fig. 3).

attached foliage of any form! However, during degaging, time and again, it was observed that primary to tertiary rachides abruptly terminated, or were bent at nearly right angle to life position, then thereafter not preserved (e.g., Fig. 7). Monsoonal disturbance, or intensive rainstorms during flooding (see below) that stripped the foliage off these axes before entombment (Tandon and Gibling 1994, 1997), is an explanation to account for the foliar litter. An alternative explanation would be that ultimate pinnae were actively abscised by the plant (comment supplied by reviewer Dr. Cleal).

Results of analyses of cuticles and macerated-only specimens show that cells of basal veins arise directly from the ultimate-pinna rachis (rachial veins), and that cells of midveins do not form a decurrent arrangement on the ultimate- pinna rachis. Coal-ball studies by Mickle and Rothwell (1982 text-Fig. 1b, d, and Table 1) show the same characteristic, particularly for Alethopteris zeilleri

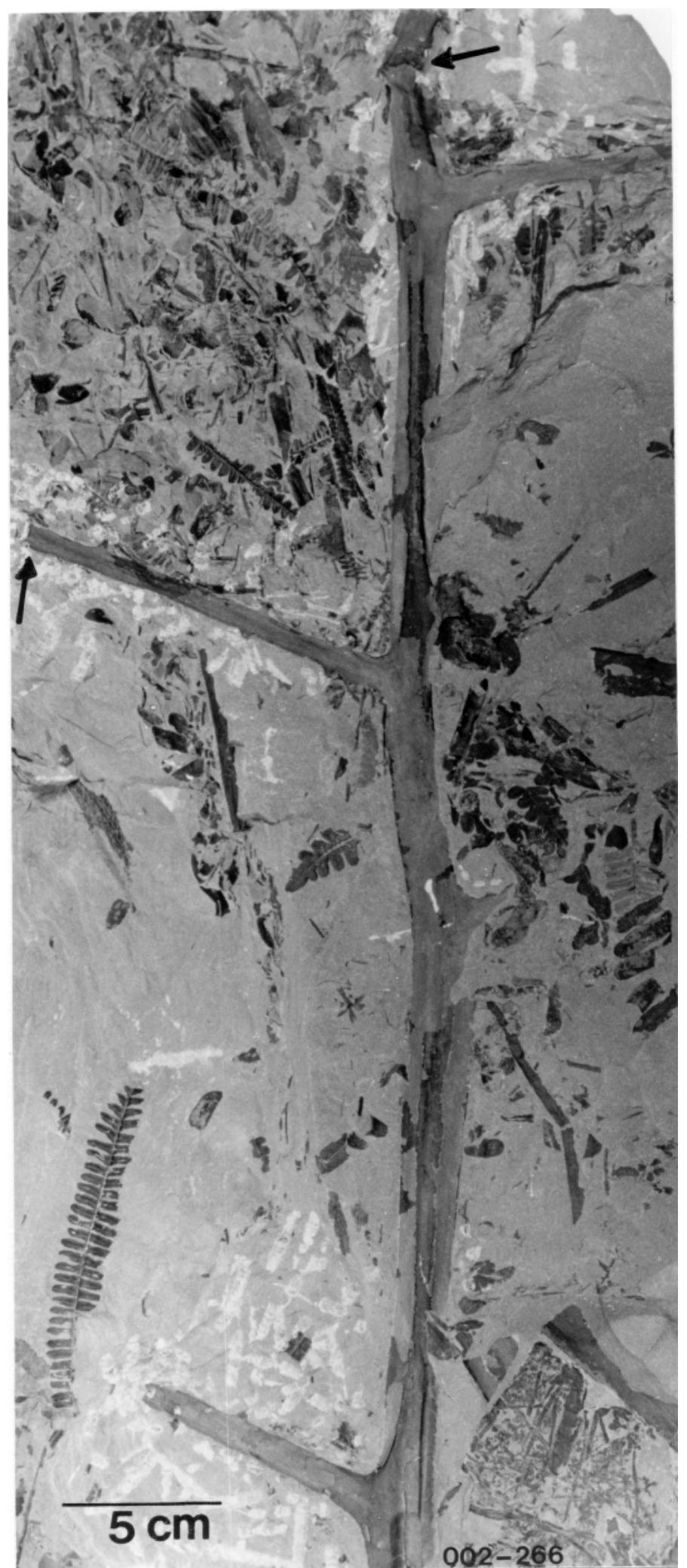

FIG. 7 A fragmentary primary-pinna rachis, $65 \mathrm{~cm}$ long with attached secondary preserved bases of ultimate-pinna rachides. Note nicked axes (arrowed). 002GF-266. 


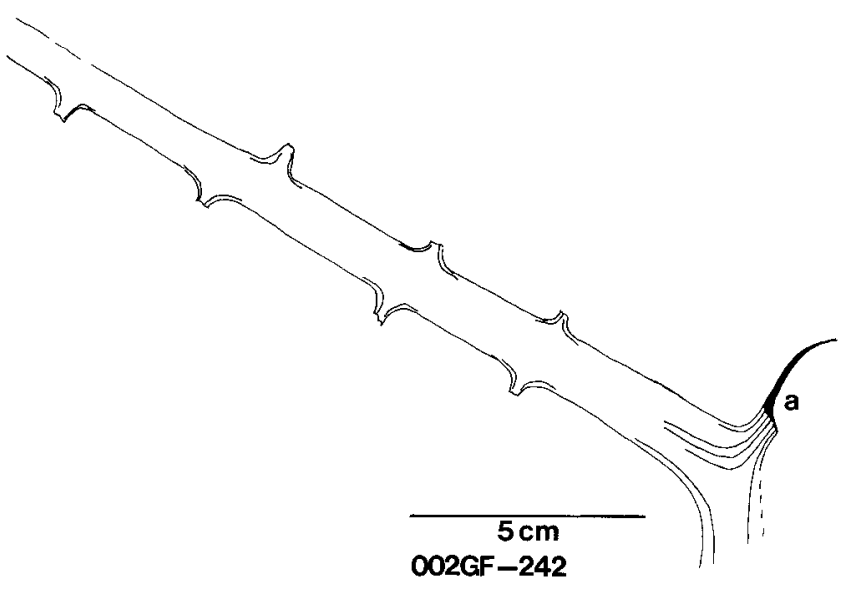

FIG. 8 (Right) Largest collected " $Y$ " axis. The right ramification (a) is twisted and entombed at right angles to the bedding plane, i.e., the cross-section width can be measured. 002GF-242.

and A. pseudograndioides var. subzeilleri. These observations call into question the generality of Bochénski's $(1960$, p. 40) claim that "....the venation in the pinnules of these species [Alethopteris Sternberg ....] is provided entirely by the midrib....".

Based on the gross morphology of compressions, the alethopterid foliage likely represents a new species for Sydney Coalfield (compare Bell 1938; Wagner 1968; Zodrow and Cleal 1998). Comparisons can be made, for example, with A. zeilleri, or its intermediate form A. pseudograndioides var. subzeilleri. However, features based on coal-ball epidermal studies for both of the species (summary: Mickle and Rothwell 1982) are difficult to correlate with the present cuticular data. In a future publication, taxonomic grouping of the present alethopterid foliage will be discussed, after the abaxial epidermis is studied.

Also, the thick alethopterid cuticle, inrolled (compression) margin, and hair are xeromorphic characters long recognized in some alethopterids (summary: Mickle and Rothwell 1982; Zodrow and Cleal 1998). Whether this can be interpreted as dry in the coal swamp is not clear, because xeromorphic characters could be the response to other factors, such as water deficiency, high-light intensity (Arens 1997), or nitrogen deficiency. A drier habitat in a local costal-plain ecosystem is suggested for the studied Lloyd Cove vegetation (Gibling and Bird 1994).

The roof rocks of the Lloyd Cove Seam are interpreted to represent a flood event. If confirmed, it is reasonable to conclude that (1) the event killed off the peat-producing vegetation which became entombed in the mud, explaining the large intact remains preserved (fragmented by mining), and (2) the coal-swamp vegetation is genetically connected with the silty-shale unit for provenance. However, evidence of rooted trunks have not been found as yet to be able to unequivocally demonstrate the existence of a species-restricted "medullosalean forest", as assumed here. From coal-ball studies by Mickle and Rothwell (1982) such situations are known.

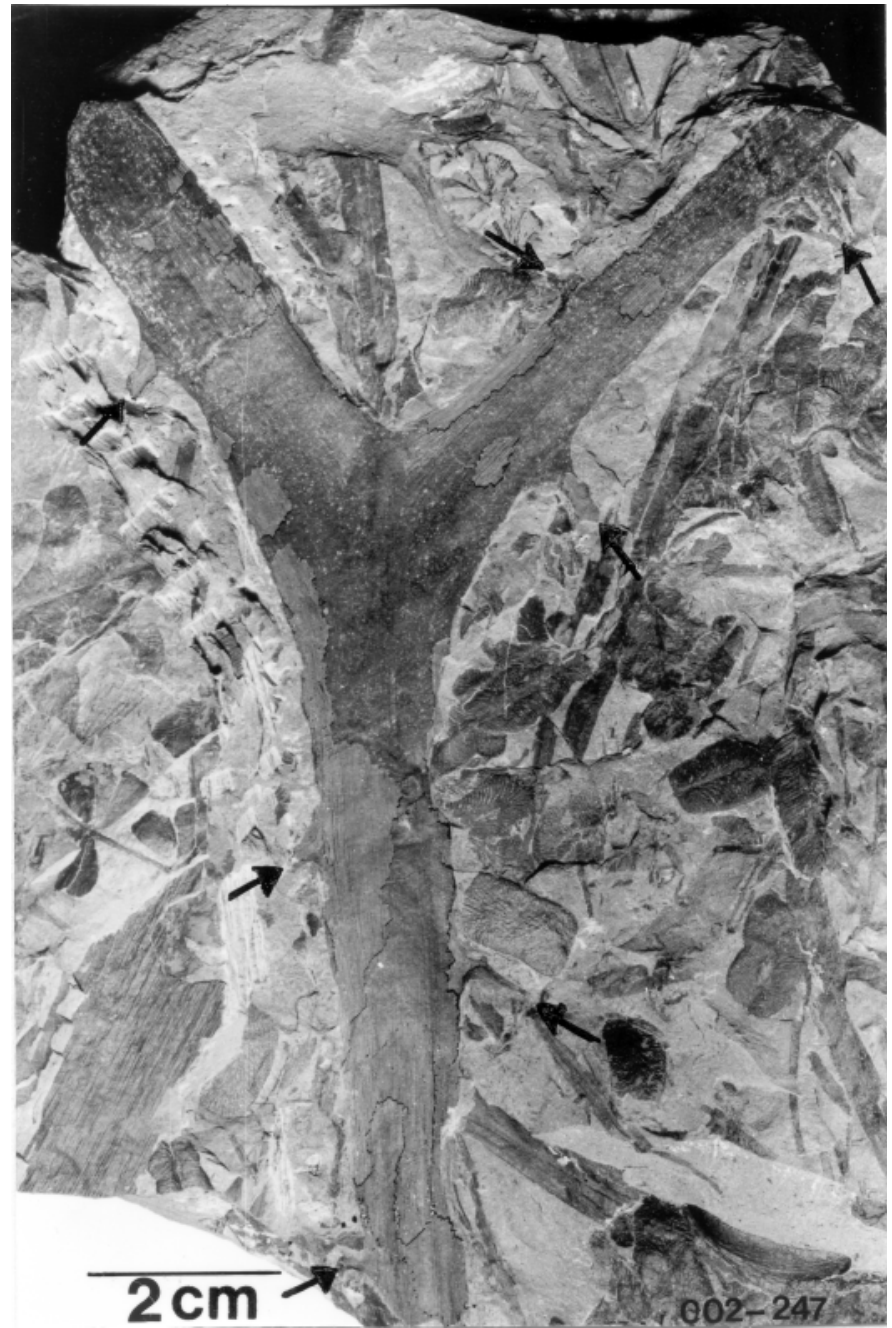

FIG. 9 A smaller "Y" axis. Arrows identify rachial bases; for details see text. 002GF-247.

The fact that biometrically the stem (Fig. 3) hardly tapers over its preserved length of $1.3 \mathrm{~m}$ is suggestive of a tall arborescentalethopterid plant.

How tall is an unanswered question because biomechanical analysis is not possible and petiolar distribution is not necessarily related to the length of the stem (see variations illustrated by Wnuk and Pfefferkorn 1984, fig. 1). The 6-cm wide petioles certainly are sturdy enough to support the weight of long fronds alethopterid is known to have borne (Laveine 1986). Fig. 18 is a reconstruction of the alethopterid tree, complete with root mantle, and is suggested to have been $5-7 \mathrm{~m}$ tall. The latter is based in part on the model by Pfefferkorn et al. (1984, figs. 1.1G and 6).

The present alethopterid tree is taller than the 2-m reconstruction by Andrews (1947), or the $3-4 \mathrm{~m}$ reconstruction by Bertrand and Corsin (1950). This is principally consistent with, but applied with caution, that based on coal-ball observations maximal sizes of arborescent trees, pteridosperms and lycophytes alike, generally increased in the Stephanian, probably evolutionarily driven (DiMichele and Phillips 1996, p. 214-215). 


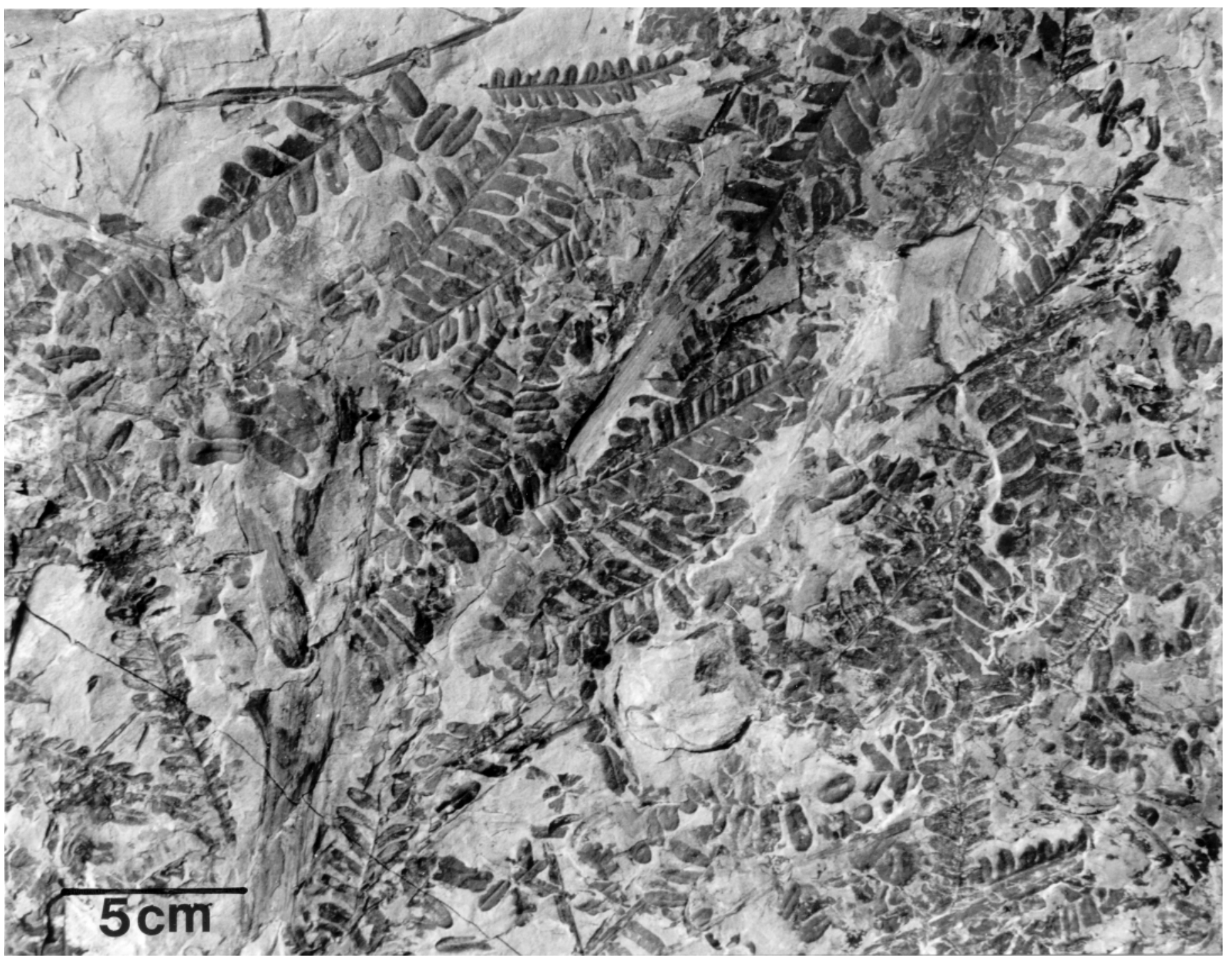

FIG. 10 Conveying the observed density of the alethopterid foliage in the open-pit mine. Field photograph of a large slab that could not be collected.

\section{Fronds}

Strictly pinnate fronds (Laveine 1997, fig. 1) are not known from the Sydney Coalfield. Instead, documented so far is a Neuropteris ovata frond with a basal dichotomy (Zodrow and Cleal 1988), a partial odontopterid frond (Zodrow 1985; Resnik 1979) of the structural Odontopteris minor-type (Laveine 1997, fig. 9), and an alethopterid frond with a prominent zigzagging primary rachis (Zodrow 1986; Zodrow and Cleal 1998). This would cover, basically, the spectrum of known bifurcate-pinnate and semipinnate fronds with imparipinnate foliage (Laveine 1997), but not the pseudopinnate frond with paripinnate foliage (e.g., linopterids). For example, Fig. 7 could fit the neuropterid, but not the linopterid-frond model because of the absence of pinnules on the rachis. Figs. 8 and 9 (and the data in Table 1) would certainly fit a zigzagging primary rachis of an alethopterid frond (Zodrow 1986, fig. 5). Of these, Fig. 8 attains special interpretative significance because it represents the best evidence for the presence of a bifurcation among the collected medullosalean axes. It compares principally with Wnuk and Pfefferkorn's (1984, fig. 7), which Laveine et al. (1993, fig. 2) interpreted as being the result of a basal alethopterid dichotomy. Fragmentary zigzagging primary rachides, $40-50 \mathrm{~cm}$ long, were found but could not be recovered from the open-pit mine.

If it is assumed that at least two of the "Y" - sample ramifications (Table 1) were contiguous in life, then reconstruction of a rachial arrangement would imply the presence of intercalated pinnate structures. This follows from the fact that on some "Y"s four orders of rachial bases are counted, including in the order the prolongation itself. Laveine et al. (1993 p. 155) had raised this point before in their frond interpretation but dismissed it on the basis for lack of evidence in the records of studied alethopterid fronds. 

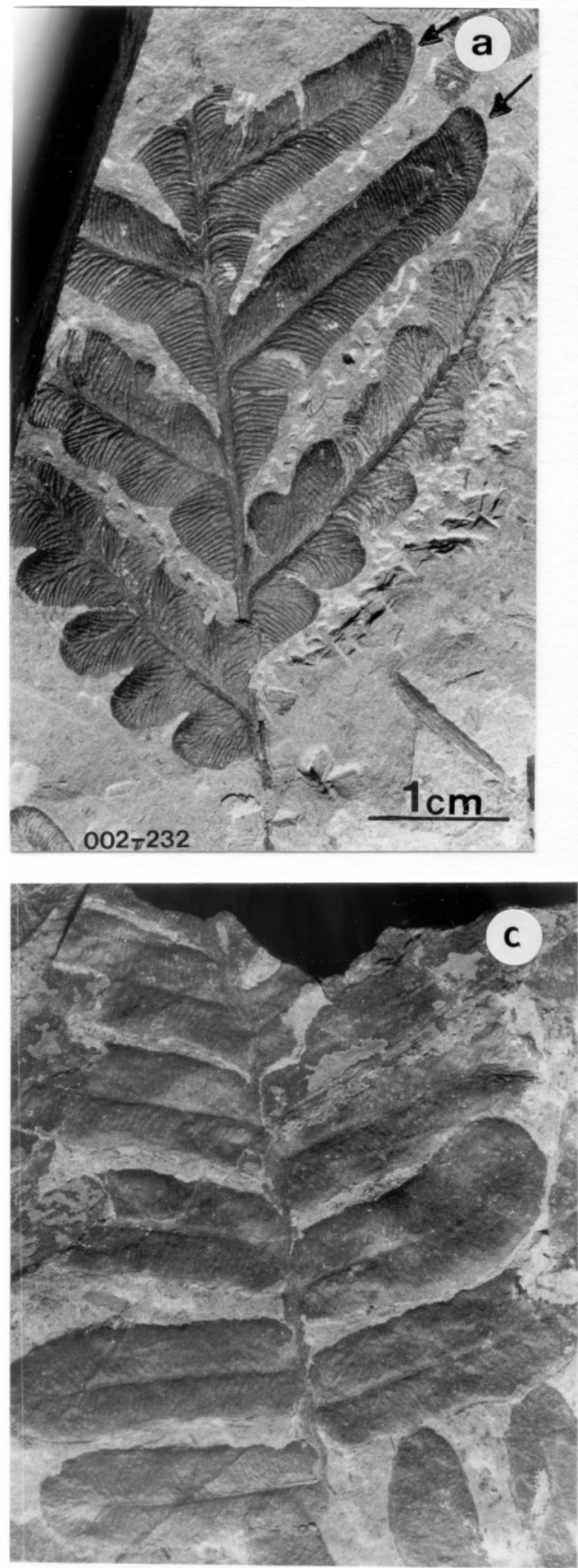

$002-234 \mathrm{~A}$
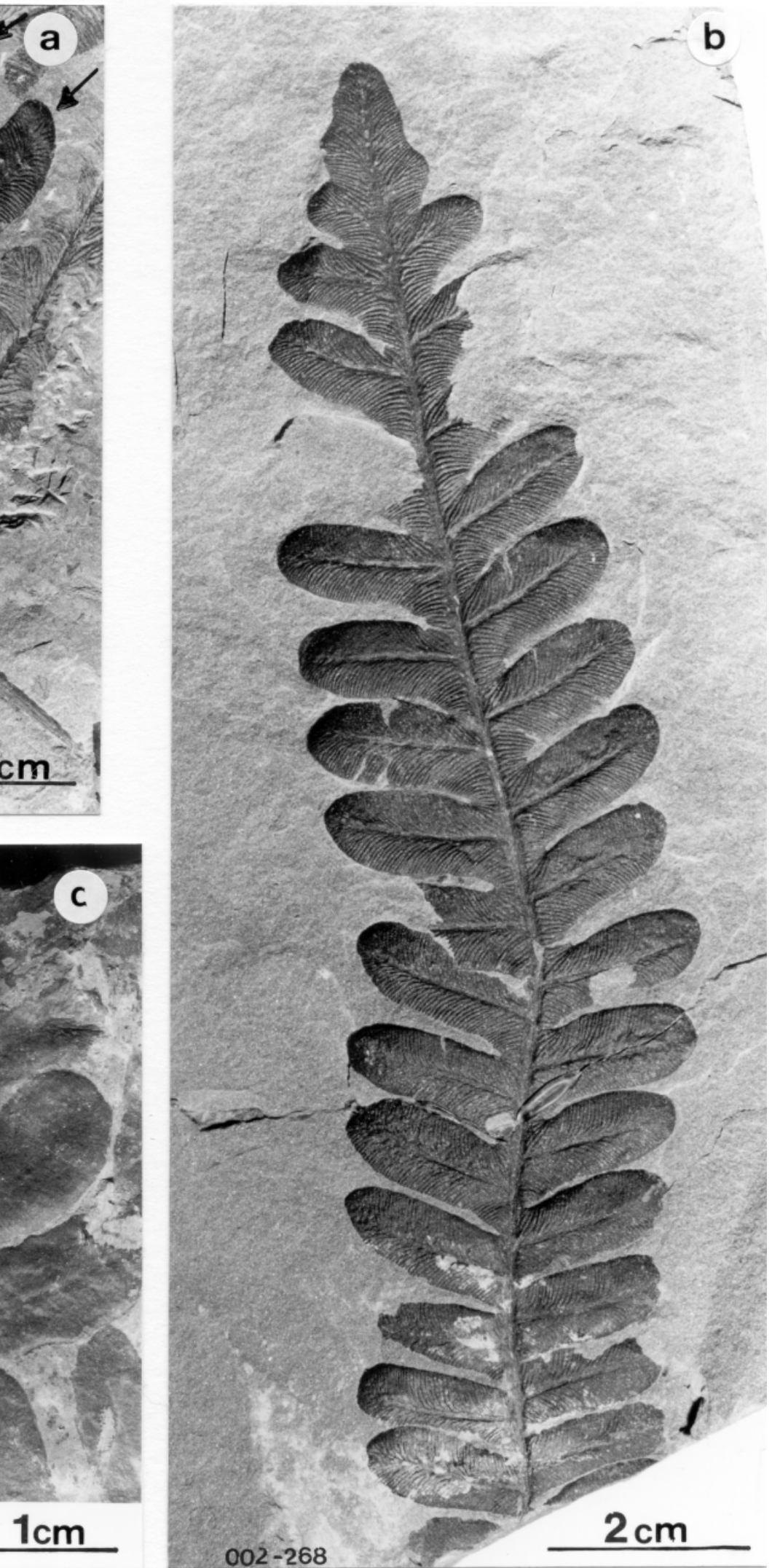

FIG. 11 Morphology of alethopterid foliage. (a) apical region showing transition from "ultimate pinna pinnule", arrowed, to pinnatifid pinnules with transitory lateral veins and subsidiary veins. 002GF-232. (b) ultimate pinna, linear in outline. 002GF-234A. (c) basal part of an ultimate pinna showing neuropteroid attachment(stalked pinnules). 002GF-268. 

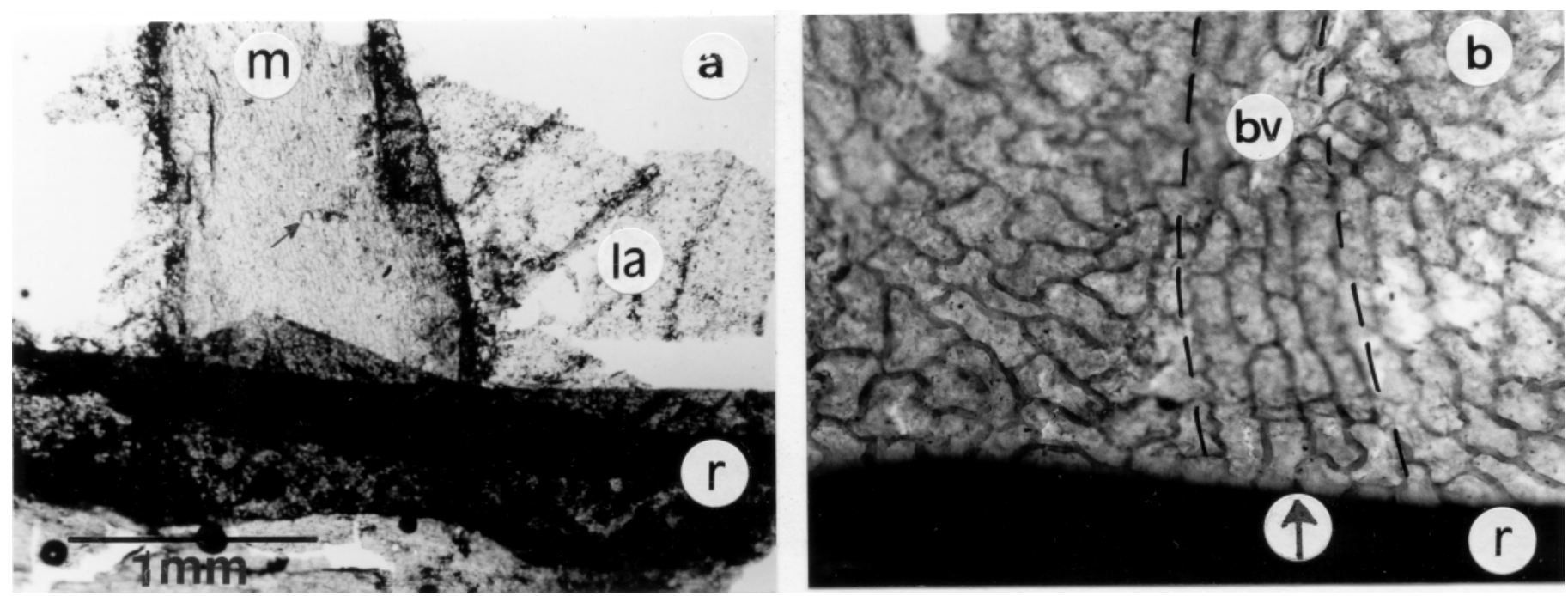

FIG. 12 Relationship of midvein $(m)$ and basal veins $(b v)$ to an ultimate pinna rachis $(r)$ in alethopterid pinnules. $(a) m$ is attached at right angle to $r$. Arrow points to a trichomal base. At right, lamina (la) attached to $r$. Macerated-only specimen. Slide 002-1. (b) bv (arrowed) arising from ris outlined. Adaxial cuticle. X110. Slide 002-307/1.

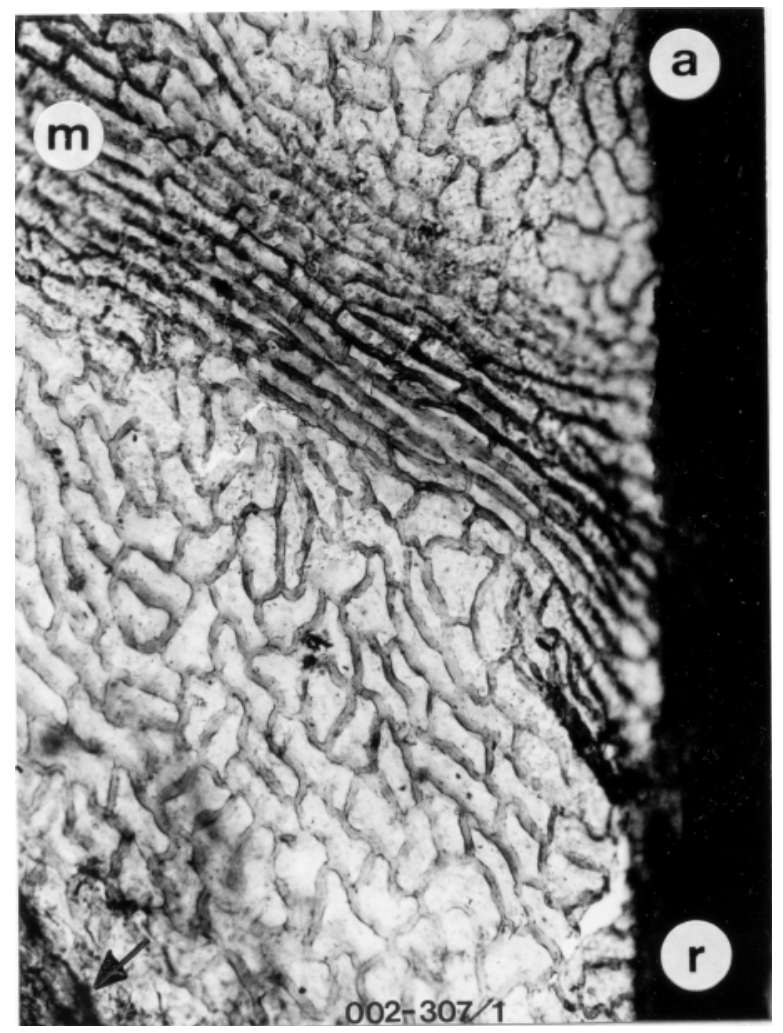

FIG. 13 Midvein cells in alethopterid cuticles. (a) cells arise at an oblique angle directly from $r$ to form $m$. Arrow points to inner edge of the compressed margin.X120. Adaxial cuticle. Slide 002-307/1. (b) cells interspersed with trichomal bases, some of which show "ring structure"(arrowed). Abaxial cuticle. X220. Slide 002-307/7.

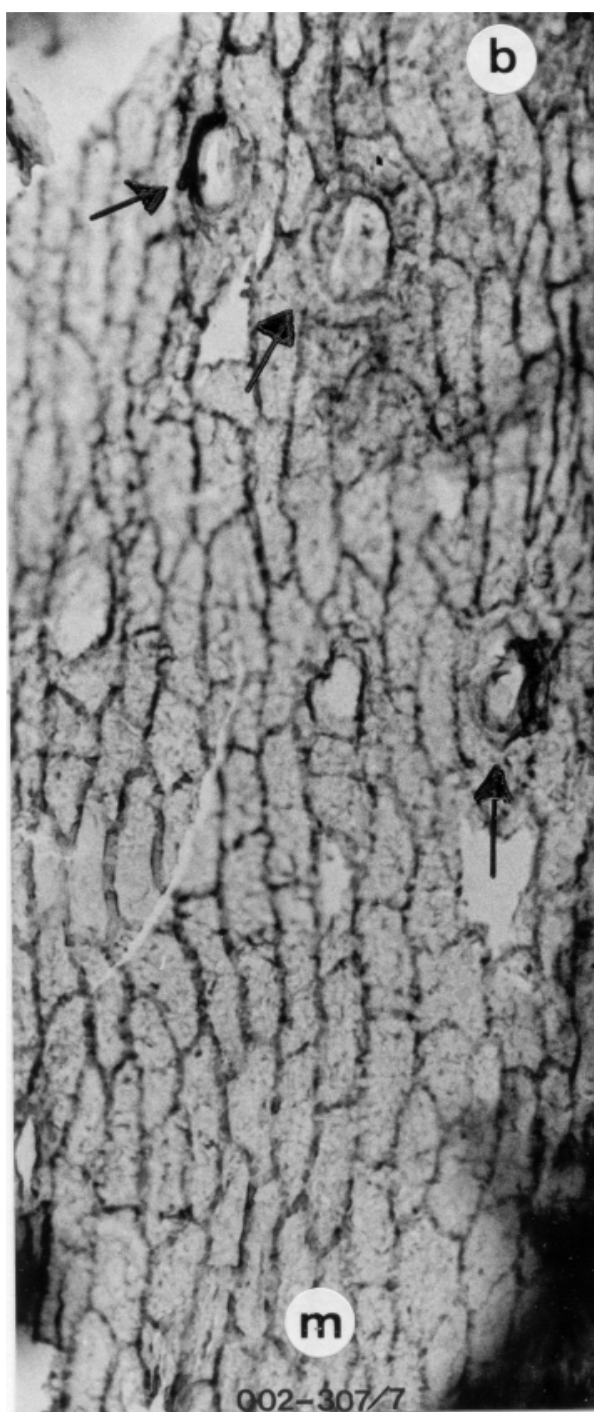




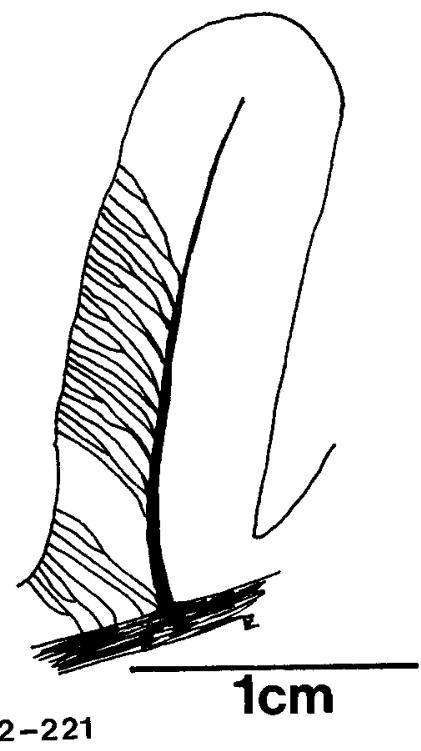

FIG. 14 Venation scheme of a larger alethopterid pinnule. 002GF-221.

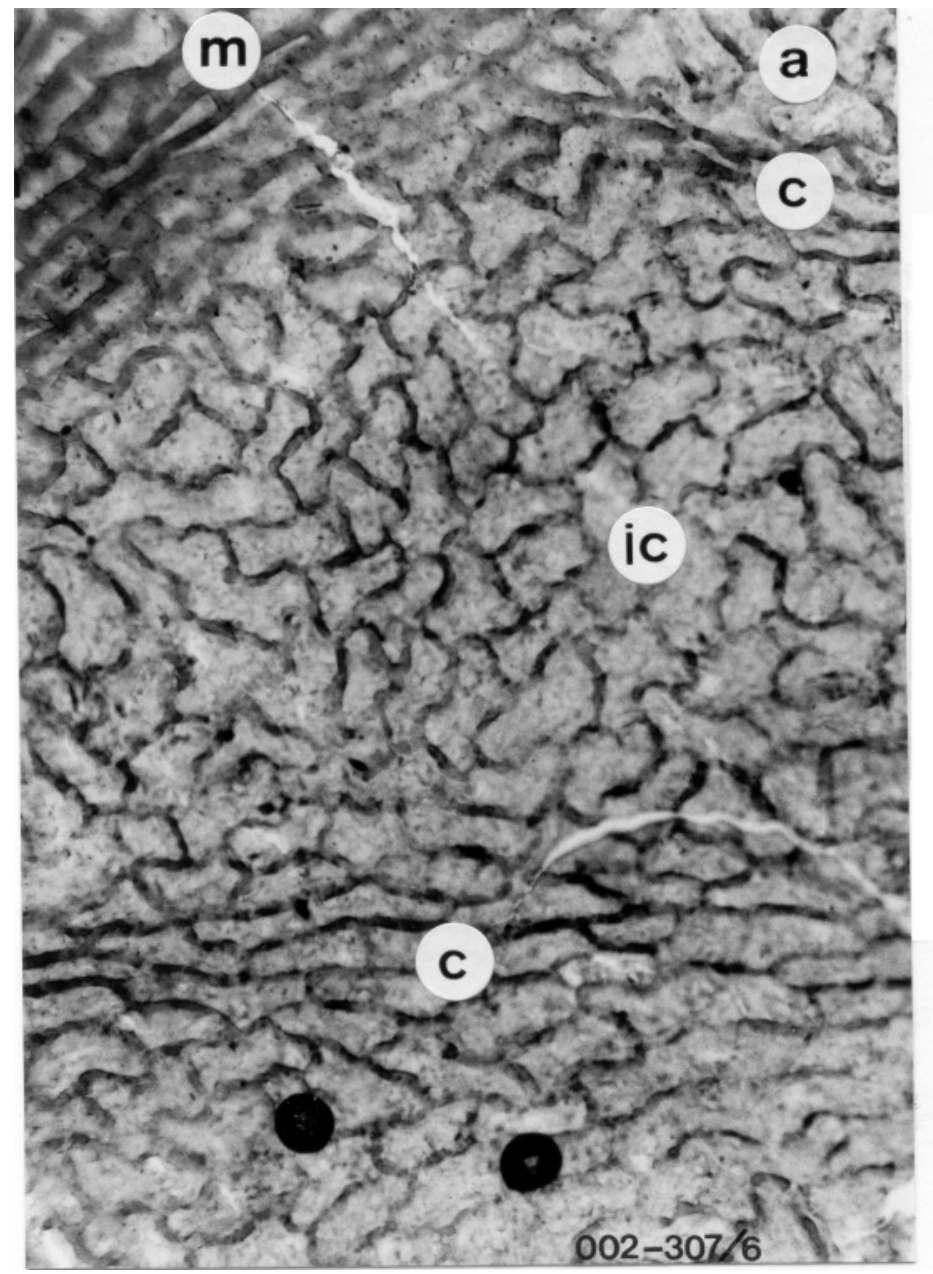

\section{Question of the number} of medullosalean trees

The question of the number of medullosalean-foliar species, and hence number of restricted pteridosperm-tree species comprising the "medullosalean forest", cannot be answered with certainty. However, the best that circumstantial evidence can provide are two independent sources of fossil finds. The argument is that (1) only three kinds of medullosalean ovules were found which are easy to determine because of differing shapes and sizes in the large open sample area, and (2) two medullosalean foliar species comprise the absolute bulk of the biomass, followed possibly by a third (Laveineopteris rarinervis, Table 2). The suggested conclusion is that "restricted" is interpreted to mean three.

\section{Identity of the petiolate stem}

In reference to the petiolate stem (trunk) (Figs. 3, 4), it is not possible to associate particular medullosalean-stem impressions with particular foliar species (Wnuk and Pfefferkorn 1984), although many species of Medullosa are already known from coalball petrifactions (Stewart and Delevoryas 1956; Basinger et al.

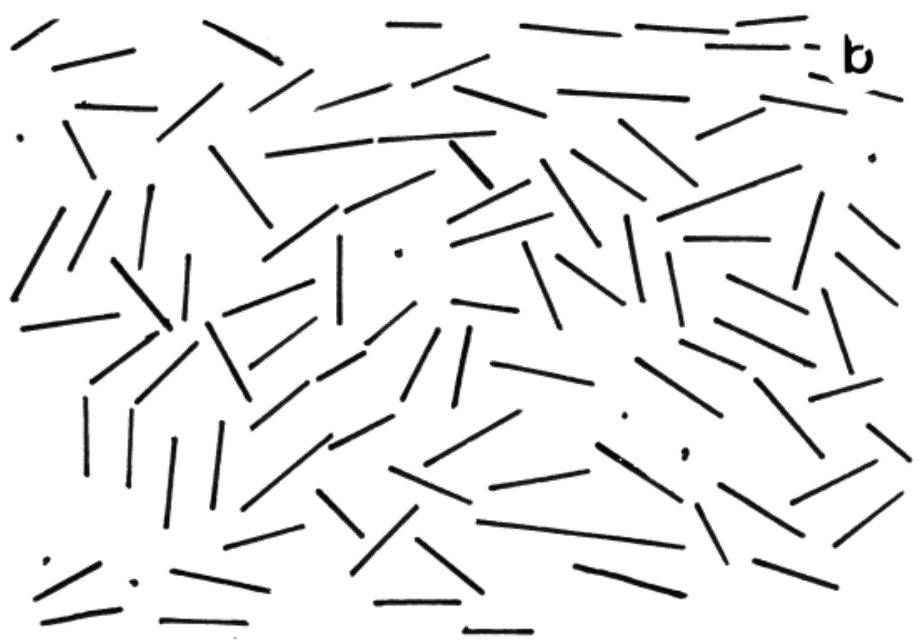

FIG. 15 Alethopterid cuticle. (a) adaxial epidermis, midvein m, costal fields (lateral vein) (c), and intercostal fields (ic).X150. Slide 002-307/ 6. (b) length and orientation of long axes of ic. Based on Fig. 15a. 

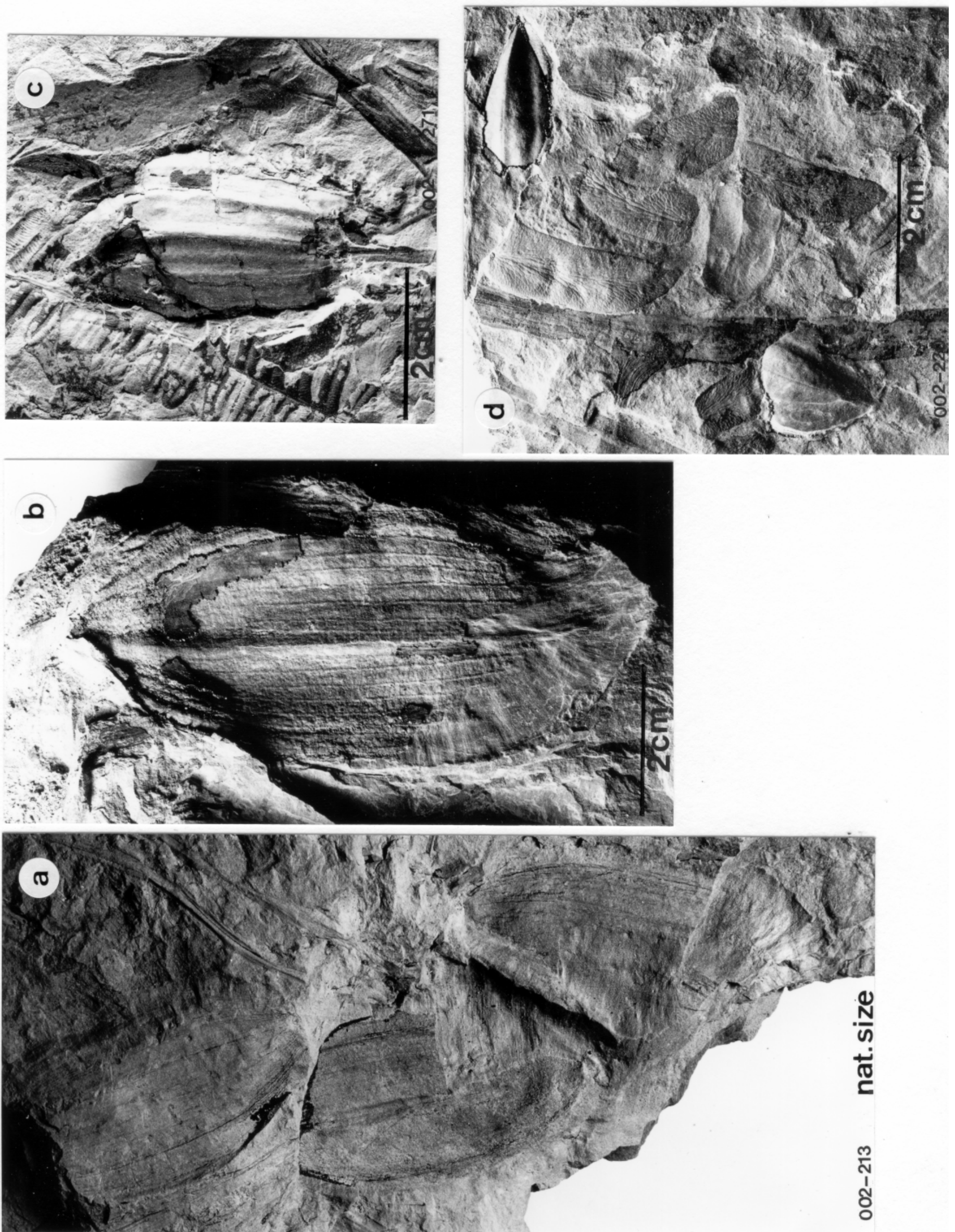


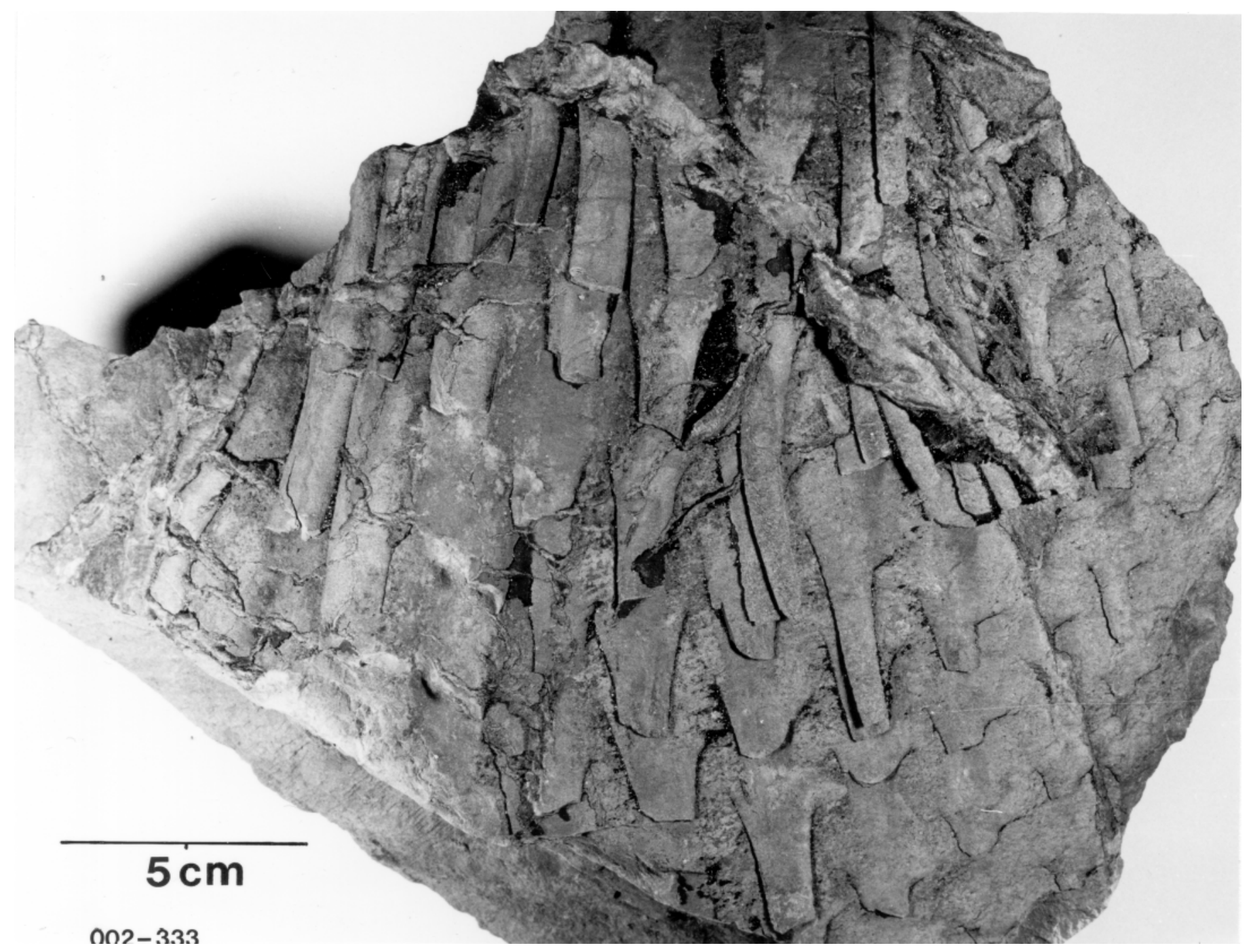

FIG. 17 A fragmentary root mantle showing adventitious roots. 002GF-333.

1974; Pryor 1990). However, circumstantial evidence exists that, for example, the petiolar scar of an abscised neuropterid frond left on a stem impression is somewhat oval in shape (Laveine and Brousmiche 1985), and that of an abscised alethopterid frond is somewhat similar (Pfefferkorn et al. 1984, fig. 2) to the "horseshoe" structure shown in Figs. 3, 4 and 6. However, this approach necessitates caution, as it is known that in arborescent pteridosperms scars change with age (summary Stewart and Delevoryas 1956, p. 60). Laveine (1997) considered that in a bifurcate-frond architecture (Neuralethopteris, Alethopteris and Lonchopteris) the petiole is "naked", as is the case in the present data of Fig. 3, for at least $60 \mathrm{~cm}$. In Neuropteris and Odontopteris, for example, the primary rachides below the main bifurcation show laminate structures such as cyclopteroid foliage. The largest, yet incomplete, frond documented of Neuropteris ovata (Zodrow and Cleal 1988) shows that aphlebioid structure appeared on the rachis below the main dichotomy ca. $18 \mathrm{~cm}$ from the medullosalean stem.

\section{CONCLUSION}

Presented is further evidence of lateral-florule changes along the $5 \mathrm{~km}$ strike distance of the Lloyd Cove Seam (basal Cantabrian), and a rare glimpse into a "three" species-restricted "medullosalean forest" that inhabited a costal plain of the Canadian Carboniferous Maritimes Basin.

Despite the numerous axes and rachides found, it is not possible to shed new light on the question of a bifurcated frond of Alethopteris, nor is it possible to assign with certainty any of the two major foliar species to any of the collected axes because of non-attachment. The evidence, such as it is, of preserved alethopterid biomass favours that the undetermined alethopterid foliage was borne on the interpreted 5-7 m tall pteridosperm tree.

If future collections at the Lloyd Cove Seam could confirm organic connection between alethopterid foliage and stems, and ovules with that attached foliage, a significant argument for advancing natural classification of the arborescent alethopterid tree is taxonomically appropriate. 


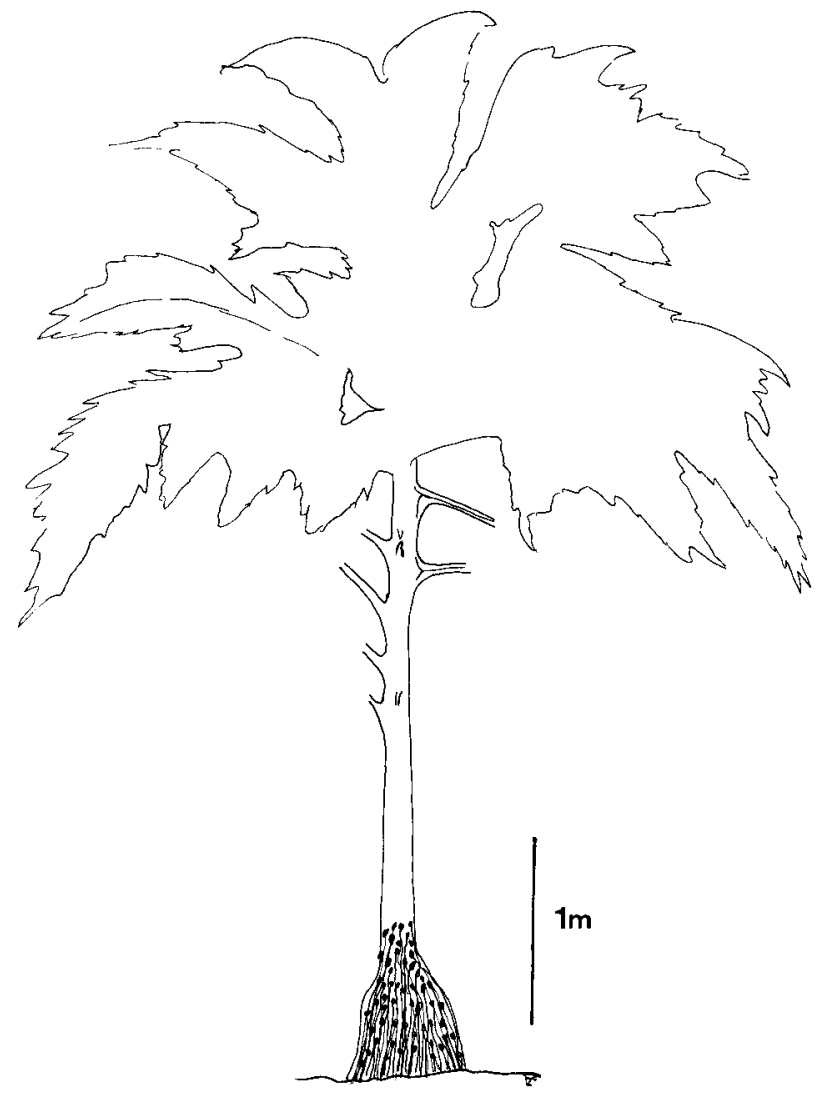

FIG. 18 Proposed arborescent alethopterid tree (adapted pro parte after Pfefferkorn et al. 1984, figs. 1.1G and 6).

\section{ACKNOWLEDGEMENTS}

The author acknowledges with gratitude the financial support received from the Natural Science and Engineering Research Council of Canada. My special gratitude goes to the Brogan's Brothers, open-pit coal-mine operators of the Lloyd Cove Seam, Cape Breton Island, Canada, for their co-operation in preserving and retrieving the large specimen, to journal reviewers Drs. C.J. Cleal and J. Galtier for their constructive advice and scholarly suggestions to improve style and content of the manuscript and to editor Dr. R. Pickevill for editorial efforts. Similarly, I thank Professor Emeritus J.-P. Laveine for critical council, and references given to me to complete this paper for a balanced discussion, and Mr. Lee Brown, formerly Sydney Mines Heritage Museum, for documentary photography in the open-pit mine.

\section{REFERENCES}

ANDrEws, H.N. 1947. Ancient plants and the world they lived in. Comstock Press, Ithaca, N.Y. 279 p., plus 166 figs.

Arens, N.C. 1997. Responses of leaf anatomy to light environment in the tree fern Cyathea caracasana (Cyatheaceae) and its application to some ancient seed ferns. Palaios, 12, pp. 84-94.

BARTHEL, M. 1961. Der Epidermisbau einiger oberkarbonischer Pteridospermen. Geologie, 7, pp. 828-849.

Barthel, M. 1962. Epidermisuntersuchungen an einigen inkohlten Pteridospermen. Geologie 11, Beiheft 33, 1-140 plus 61 pls.

Basinger, J.E., Rothwell, G.W., \& Stewart, W.N. 1974. Cauline vasculature and leaf trace production in medullosan pteridosperms. American Journal of Botany, 61, pp. 1002-1015.

BELL, W.A. 1938. Fossil flora of Sydney Coalfield, Nova Scotia. Geological Survey of Canada, Memoir 215, 334 p.

Bertrand, P., \& Corsin, P. 1950. Reconstruction de tableaux de végétation fossiles. Annales de Paléontologie, 36, pp. 126144.

BochÉnsKi, T. 1960. Rozwoj unerwienia listeczkow u Karbonskich paproci nasiennych Alethopterides (Alethopteris I Lonchopteris) oraz znaczenie analizy ich unerwienia dla diagnozy gattunku. Instytut Geologiczny, prace tome XX: 1-42 plus XI pls. Polish with English translation.

Buisine, M. 1961. Les Aléthoptéridées du Nord de la France. Ét. Géol. Atlas Topo. Souterre, 1, 1-317 plus 74 pls.

Cleal, C.J., Tenchov, Y., Dimitrova, T.K.H., \& Zodrow, E.L. 2002. Climatic and vegetational changes in the late Carboniferous tropical belt. NATO Science Programme-Project EST-CLS 976716, 117 p.

Cleal, C.J., Dimitrova, T.K.H., \& Zodrow, E.L. 2003. Macrofloral and palynological criteria for recognising the Westphalian-Stephanian boundary. News Letter Stratigraphy. 39 (2/3), pp. 181-208.

Darrah, W.C. 1969. A critical review of the Upper Pennsylvanian floras of eastern United States with notes on the Mazon Creek Flora of Illinois, 220 p. plus 80 pls.

DiMichele, W.A., \& Phillips, T.L. 1996. Climate change, plant extinctions and vegetational recovery during the Middle-Late Pennsylvanian transition: the case of tropical peat-forming environments in North America. In M.B. Hart (ed.), Biotic Recovery from Mass Extinction Events. Geological Society, Special Publication 102, pp. 201-221.

DiMichele, W.A., Stein, W.E., \& Bateman, R.M. 2001. Ecological sorting of vascular plant classes during the Paleozoic evolutionary radiation. In Evolutionary Paleoecology: The Ecological Context of Macroevolutionary Change. Edited by W.D. Allmon, and D.J. Bottjer. Columbia University Press, New York, pp. 285-335.

Frye, K. 1993. Mineral Science. An introductory survey. Macmillan Publishing Co. New York, 360 p.

Garrels, R.M., \& Christ, C.L. 1965. Solutions, Minerals, and Equilibria. Harper and Row, New York, 450 p.

GASTALDO, R.H. 1990. Earliest evidence for helical crown configuration in a Carboniferous tree of uncertain affinity. Journal of Paleontology, 64, pp. 146-151.

Gibling, M.R., \& BiRD, D.J. 1994. Late Carboniferous cyclothems and alluvial palaeovalleys in the Sydney Basin, Nova Scotia. Geological Society of America Bulletin, 106, pp. 105-117. 
Hacquebard, P.M., \& Cameron, A.R. 1989. Distribution of coalification patterns in Canadian bituminous and anthracite coals. International Journal of Coal Geology, 13 pp. 207-260.

Heg gie, M., \& Zodrow, E.L. 1994. Fractal lobatopterid frond (Upper Carboniferous marattialean tree fern). Palaeontographica Abt. B. 232:35-57.

LAVEINE, J.-P. 1986. The size of the frond in the genus Alethopteris Sternberg(Pteridospermopsida, Carboniferous). Geobios, 19, pp. 49-56.

Laveine, J.-P. 1997. Synthetic analysis of the Neuropterids. Their interest for the Decipherment of Carboniferous palaeogeography. Review of Paleobotany and Palynology, 95 pp. 155-189.

Laveine, J.-P., \& Brousmiche, C. 1985. Observation d'un fragment de tronc probablement de Neuropteris au toit de la veine San Juan, Carrière Abeduriu, Bassin des Asturies. C.R. Xe Congrès International de Stratigraphie et de Géologie du Carbonifère. Madrid September 12-17, 1983, 2, pp. 137-140.

Laveine, J.-P., Belhis, A., Lemoigne, Y., \& Zhang, S. 1993. Frond architecture in the genera Neuralethopteris Cremer, Alethopteris Sternberg, and Lonchopteris Brongniart (Carboniferous pteridosperms). Revue Palaeobiologie, 6, pp. 149-166.

Mickle, J.E., \& Rothwell, G.W. 1982. Permineralized Alethopteris from the Upper Pennsylvanian of Ohio and Illinois. Journal of Paleontology, 56, pp. 392-402.

Pfefferkorn, H.W., Gillespie, W.H., Resnik, D.A., \& Scheining, M.H. 1984. Reconstruction and architecture of medullosan pteridosperms (Pennsylvanian). The Mosasaur, 2, pp. 1-8.

Phillips, T.L., Peppers, R.A., \& DiMichele, W.A. 1985. Stratigraphic and interregional changes in Pennsylvanian coal-swamp vegetation: Environmental inferences. International Journal of Coal Geology, 5, pp. 43-109.

PRYOR, J.S. 1990. Delimiting species among permineralized medullosan pteridosperms: a plant bearing Alethopteris fronds from the Upper Pennsylvanian of the Appalachian basin. Canadian Journal of Botany, 68, pp. 184-192.

Ramanujam, C.G.K., Rothwell, G.W., \& Stewart, W.N. 1974. Probable attachment of the Dolerotheca campanulum to a Myeloxylon-Alethopteris type of frond. American Journal of Botany. 61, pp. 1057-1066.

Remy, W., \& Remy, R. 1977. Die Floren des Altertums. Verlag Glueckauf, Essen, 468, p.

ResNiK, D.A. 1979. Revision of the genus Odontopteris (Pteridosperms, Pennsylvanian-Permian) in North America. Unpublished MSc thesis, University of Pennsylvania, $96 \mathrm{p}$.

Rex, G.M., \& Chaloner, W.G. 1983. The experimental formation of plant compression fossils. Palaeontology, 26, pp. 231-252.

Stewart, W.N., \& Delevoryas, T. 1956. The medullosan pteridosperms. The Botanical Review. 22, pp. 45-80.

TAndon, S.K., \& Gibling, M.R. 1994. Coal and calcrete in Late Carboniferous cyclothems of Nova Scotia: climate and sea-level changes linked. Geology, 22, pp. 755-758.

Tandon, S.K., \& Gibling, M.R. 1997. Calcretes at sequence boundaries in Upper Carboniferous cyclothems of the
Sydney Basin, Atlantic Canada. Sedimentary Geology, 112, pp. 43-67.

WAGNER, R.H. 1968. Upper Westphalian and Stephanian species of Alethopteris from Europe, Asia Minor and North America. Mededelingen van de Rijks Geologische Dienst, Maastricht, Serie C, III-1-No. 6, 319 p.

Wightman, W.G., Sсотt, D.B., Medioli, F.S., \& Gibling, M. R. 1994. Agglutinated foraminifera and thecamoebians from the Late Carboniferous Sydney coalfield, Nova Scotia: paleoecology, paleoenvironments and paleogeographical implications. Palaeogeography, Palaeoclimatology, Palaeoecology, 106, pp. 187-202.

Wnuk, C., \& Pfefferkorn, H.H. 1984. The life habits and palaeoecology of Middle Pennsylvanian medullosan pteridosperms based on in situ assemblage from the Bernice Basin (Sullivan County, Pennsylvania, U.S.A.). Review of Palaeobotany and Palynology, 41, pp. 329-351.

Zodrow, E.L. 1985. Odontopteris Brongniart in the Upper Carboniferous of Canada. Palaeontographica Abt. B, 196, pp. 79-110.

ZoDRow, E.L. 1986. Succession of palaeobotanical events: Evidence for Mid-Westphalian D floral changes, Morien Group (Late Pennsylvanian, Nova Scotia). Review and Palaeobotany and Palynology. 47, pp. 293-326.

Zodrow, E.L. 1990. Revision and emendation of Pecopteris arborescens Group, Permo-Carboniferous. Palaeontographica Abt. B, 217, pp. 1-49.

Zodrow, E.L., \& Cleal, C.J. 1985. Phyto- and chronostratigraphical correlations between the late Pennsylvanian Morien Group (Sydney, Nova Scotia) and the Silesian Pennant Measures (south Wales). Canadian Journal of Earth Sciences, 22, pp. 1465-1473.

Zodrow, E.L., \& Cleal, C.J. 1988. The structure of the Carboniferous pteridosperm frond Neuropteris ovata Hoffmann. Palaeontographica Abt. B, 208, pp. 105-124.

Zodrow, E.L., \& CleAL, C.J. 1998. Revision of the pteridosperm foliage Alethopteris and Lonchopteridium (Upper Carboniferous), Sydney Coalfield, Nova Scotia, Canada. Palaeontographica Abt. B, 247, pp. 65-122.

Zodrow, E.L., \& Mastalerz, M. 2001. Chemotaxonomy for naturally macerated tree-fern cuticles (Medullosales and Marattiales), Carboniferous Sydney and Mabou Sub-basins, Nova Scotia, Canada. International Journal of Coal Geology, 47, pp. 255-275

Zodrow, E.L., \& MAstalerz, M. 2002. FTIR and py-GC-MS spectra of true-fern and seed-fern sphenopterids (Sydney Coalfield), Nova Scotia, Canada, Pennsylvanian. International Journal of Coal Geology, 51, pp. 111-127.

Zodrow, E.L., \& McCANDLISH, K. 1978. Distribution of Linopteris obliqua in the Sydney Coalfield of Cape Breton, Nova Scotia. Palaeontographica Abt. B, 168, pp. 1-16.

Zodrow, E.L., ŠIMŮNeK, Z., \& BASHForTh, A.R. 2000. New cuticular morphotypes of Cordaites principalis from the Canadian Carboniferous Maritimes Basin. Canadian Journal of Botany, 78, pp. 135-148. 


\section{APPENDIX 1}

Acitheca polymorpha (Brongniart) Schimper Alethopteris ambigua (Lesquereux pars) Zodrow and Cleal Alethopteris pseudograngioides var. subzeilleri Wagner Alethopteris sp. Sternberg

Alethopteris zeilleri (Ragot) Wagner

Annularia sp. Sternberg

Aphlebia sp. Presl

Cordaites multiramis Weiss

Cordaites sp. Unger

Dicksonites plueckenetii (Schlotheim) Sterzel

Laveineopteris rarinervis (Bunbury) Cleal, Shute and Zodrow Leeites oblongifolis Zodrow and Gao

Linopteris brongniartii (Gutbier) Potonié

Linopteris obliqua (Bunbury) Zeiller

Linopteris sp. Presl

Lonchopteris Brongniart

Macroneuropteris macrophylla (Brongniart)

Cleal, Shute and Zodrow

\author{
Medullosa sp. Cotta \\ Neuralethopteris sp. Cremer \\ Neuropteris cf. flexuosa Sternberg \\ Neuropteris ovata Hoffmann emend. Zodrow and Cleal \\ Odontopteris minor Brongniart \\ Pecopteris abbreviata Brongniart \\ Pecopteris hemitilioides? Brongniart \\ Pecopteris unita Brongniart \\ Rhabdocarpus Göppert and Berger \\ Sphenophyllum costae (Sterzel) Teixeira emend. Zodrow \\ Sphenophyllum cuneifolium (Sternberg) Zeiller \\ Sphenophyllum emarginatum (Brongniart) Brongniart emend. \\ Batenburg \\ Sphenophyllum oblongifolium (Germer and Klaulfuss) \\ Unger emend. Barthel \\ Trigonocarpus Brongniart-Holcospermum Nathorst
}


